\title{
Secuencia constructiva de la iglesia de Santiago en Peñalba de Santiago (Ponferrada, León). Reformas de un edificio unitario
}

\author{
Constructive sequence of the Church of Santiago in Peñalba de Santiago \\ (Ponferrada, León). Reforms of an unitary building
}

José Ignacio Murillo Fragero*

\begin{abstract}
RESUMEN
Revisitar científicamente un edificio como la iglesia del municipio de Santiago de Peñalba desde el ámbito metodológico de la Arqueología de la Arquitectura nos ha permitido ofrecer una propuesta más ajustada sobre aspectos relativos a su construcción y el origen de los materiales empleados, incluidas las sucesivas reformas que la investigación precedente ya había puesto de relieve. En este sentido, el principal resultado del análisis confirma que el edificio fue diseñado y construido de forma unitaria, levantándose todos sus tramos al mismo tiempo. Por otro lado, el acceso a las zonas altas y cubiertas del edificio, gracias a los andamios facilitados por las obras de restauración en marcha, permitió obtener una nueva perspectiva de algunos elementos. De este modo, ahora contamos con un inventario de los canes de los aleros de la iglesia, entre los cuales destaca un importante conjunto de modillones polilobulados producidos por un taller leonés que también actuó en los monasterios de San Miguel de Escalada (León), San Cebrián de Mazote (Valladolid) y San Salvador de Palat del Rey (León).
\end{abstract}

Palabras clave: Alta Edad Media, Prerrománico, Mozárabe, Arqueología de la Arquitectura, análisis estratigráfico, dendrocronología, material constructivo reutilizado, modillones polilobulados.

\section{INTRODUCCIÓN}

Han transcurridos ya 100 años desde que el investigador M. GÓMEZ-MORENO (1909, 1919, y 1925) analizara y pusiera en valor las principales características de la iglesia de Santiago de Peñalba, certeras descripciones de carácter histórico y constructivo que se

\begin{abstract}
Scientifically revisiting a building as the church of the municipality of Santiago de Peñalba from the methodological field of Archaeology of Architecture has enabled us to provide a more accurate proposal on those aspects regarding its construction and the origin of the materials used, including the subsequent reforms that the previous investigation had already considered. In this sense, the main result of the analysis confirms that the building was designed and built as a unit, erecting all sections simultaneously. On the other hand, access to the upper parts and roofs of the building, thanks to the scaffoldings installed by the ongoing restoration project, made possible to gain a new perspective of some of its elements. We have thus an inventory of the corbels from the eaves of the church, among them an important set of modillones polilobulados (multi-lobes-corbels) produced by a workshop from Leon that also worked in the monasteries of San Miguel de Escalada (Leon), San Cebrián de Mazote (Valladolid) and San Salvador de Palat del Rey (León).
\end{abstract}

Key words: Early Middle Ages, Pre-Romanesque, Mozarabic, Archaeology of Architecture, stratigraphic analysis, dendrochronology, reused building material, modillones polilobulados (multi-lobes-corbels).

han completado en la última década gracias a los resultados aportados por las labores de restauración y de excavación arqueológica ${ }^{1}$.

Con el objetivo de mejorar su conocimiento, aportando una nueva perspectiva desde el ámbito metodológico de la Arqueología de la Arquitectura (CABALLERO, LATORRE, 1995;

* Arqueólogo, Urbe pro Orbe

1 Restauración del acabado interior del edificio llevada a cabo bajo la coordinación de la restauradora María Suárez-Inclán entre los años 2002 y 2004 y excavación arqueológica al interior y al exterior del edificio llevada a cabo bajo la coordinación del arqueólogo José Luis Cortés Santos entre los años 2002 y 2004. 
CABALLERO, ESCRIBANO, 1996), presentamos a continuación los principales resultados del análisis estratigráfico ${ }^{2}$ llevado a cabo en el conjunto monumental. Este trabajo, como recogen sus conclusiones, nos ha permitido revisar las propuestas tradicionales y corregir otras más recientes.

\section{FUENTES ACERCA DE LA FUNDACIÓN Y CONSTRUCCIÓN DE LA IGLESIA DE SANTIAGO}

A lo largo de los siglos IX y X, la comarca del Bierzo es un entorno tradicional de ocupación monástica y cenobítica (ÁLVAREZ, 1954; RODRÍGUEZ GONZÁLEZ, 1997; DURANY, RODRÍGUEZ, 1998), donde existe constancia documental de la participación directa del obispo de Astorga, Genadio, en diferentes fundaciones, consagraciones y restauraciones, actividad que pudo contar con patrocinio real (QUADRADO, 1885: 629; MARTÍNEZ TEJERA, 2010). Para diversos autores (GÓMEZ-MORENO, 1919: 224-225), el denominado testamento de Genadio (MORALES, 1791: T.VI, 291-297), fechado no más tarde del año 919, permite entrever que entre sus objetivos estaba la promoción del monasterio de Santiago, para la cual pudo contar con el apoyo de Alfonso III (GUARDIA PONS, 2007: 118).

Sin embargo, la documentación no permite certificar si a la muerte de Genadio la iglesia del monasterio había comenzado a construirse o no. De hecho, una inscripción incisa sobre el revoco fresco que recubre la imposta del ábside oriental parece indicar que pudo consagrarse en tiempos del sucesor de Genadio en Astorga, Salomón, durante el año 937 del calendario actual (GUARDIA PONS, 2007: 118119), fecha que, por otro lado, es coincidente con la propuesta tradicional que se desprende de las fuentes del periodo (GÓMEZ-MORENO, 1919: 226).

El análisis de esta documentación ha permitido defender la idea de que los restos de Genadio fueron trasladados a Santiago de Peñalba (YEPES, 1609-1621: T.1, Cap. XXXII, 162) y sepultados junto a los de Urbano, en el contraábside de la iglesia, actuando este espacio como mausoleo (GÓMEZ-MORENO, 1925: 115).

Corroborando lo anteriormente indicado, durante el obispado de Salomón la Iglesia recibió dotaciones indeterminadas para el templo berciano dedicado a Santiago, como las ofrecidas el año 940 por Ramiro II (QUINTANA, 1956; GUARDIA PONS, 2007: 119; ambos a partir del Tumbo Negro de la Catedral de Astorga, Biblioteca Nacional de España, Sección Manuscritos, Sign. Mss. 4357). En el siglo XII quedará anexionada a la Catedral de Astorga como priorato (QUADRADO 1885: 630; GÓMEZ-MORENO, 1919: 226).

\section{GEOLOGÍA Y PRECEDENTES A LA IGLE- SIA DE SANTIAGO}

La formación geológica de la localidad de Peñalba de Santiago, situada a media ladera de una fuerte pendiente, presenta un substrato producto de arrastres con un techo de baja compactibilidad formado por pequeñas lajas de pizarras cuarcíticas y esquistos mezcladas con arcillas limpias. La excavación arqueológica efectuada en el solar de la iglesia el año 2002 puso de evidencia que el edificio no fue construido sobre estructuras precedentes (CORTÉS SANTOS, 2005). Con posterioridad a su construcción, la cabecera del templo quedo parcialmente enterrada por diferentes ciclos de arrastre ladera abajo, proceso que fue interrumpido con recientes obras de

\footnotetext{
2 Los resultados que aquí se presentan derivan del análisis de Arqueología de la Arquitectura efectuado en la iglesia de Santiago en el marco de los trabajos de reconstrucción de sus cubiertas, proyecto firmado por los arquitectos Ángel Carmelo Cepeda Martín y Pedro Luis Gallego Fernández, el cual se llevó a cabo a lo largo del año 2015 por la empresa Estudios y Obras Campo, S.L. (ESOCA). Las actividades mencionadas fueron encargadas por el Servicio de Restauración de la Consejería de Cultura y Turismo de la Junta de Castilla y León y cofinanciadas con cargo al Fondo Europeo de Desarrollo Regional (FEDER). El análisis estratigráfico se ha llevado a cabo por el equipo de arqueólogos compuesto por José Ignacio Murillo Fragero (responsable científico y técnico) y Carlos Cauce Cañizares, miembros de Urbe pro Orbe, con el asesoramiento científico de María de los Ángeles Utrero Agudo y Alejandro Villa del Castillo, ambos miembros del IH-CSIC.
} 
alcantarillado (Año 1985) y de urbanización (Año 1997). Sin embargo, el resto del perímetro de la iglesia no ofrece ningún tipo de acumulación, probablemente por la existencia a su alrededor desde fechas tempranas de edificaciones y cercas delimitadoras (CORTÉS SANTOS, 2005: 167-168).

\section{SECUENCIA CONSTRUCTIVA DE LA IGLESIA ${ }^{3}$}

\section{Fase 1a. Construcción de la iglesia:} Alto medievo

A100, UE1000 101310181024102810341053

10741100

La iglesia de Santiago se compone de una nave principal, dividida en dos tramos de plan- ta cuadrada (UE1034), rematada a Este y Oeste por dos ábsides y flanqueada por dos habitaciones de planta cuadrada en su tramo más oriental. Los ábsides contrapuestos presentan un desarrollo interior curvo peraltado (ábside oriental -UE1000- y occidental -UE1053-) y las dos habitaciones laterales corresponden a capillas o sacristías (habitación sur -UE1013-y habitación norte -UE1024-). Los espacios mencionados presentan las siguientes medidas en planta, tomada sobre la planimetría (Fig. 1):

\begin{tabular}{|l|c|c|c|}
\hline Espacios (exterior) & UE & Longitud & Anchura \\
\hline Ábside oriental & 1000 & $4,51 \mathrm{~m}$ & $4,97 \mathrm{~m}$ \\
\hline Ábside occidental & 1053 & $4,71 \mathrm{~m}$ & $4,94 \mathrm{~m}$ \\
\hline Tramo oriental de la nave & 1034 & $6,37 \mathrm{~m}$ & $6,55 \mathrm{~m}$ \\
\hline Tramo occ. de la nave & 1034 & $6,84 \mathrm{~m}$ & $6,55 \mathrm{~m}$ \\
\hline Habitación lateral norte & 1024 & $4,16 \mathrm{~m}$ & $4,65 \mathrm{~m}$ \\
\hline Habitación lateral sur & 1013 & $4,12 \mathrm{~m}$ & $4,79 \mathrm{~m}$ \\
\hline
\end{tabular}

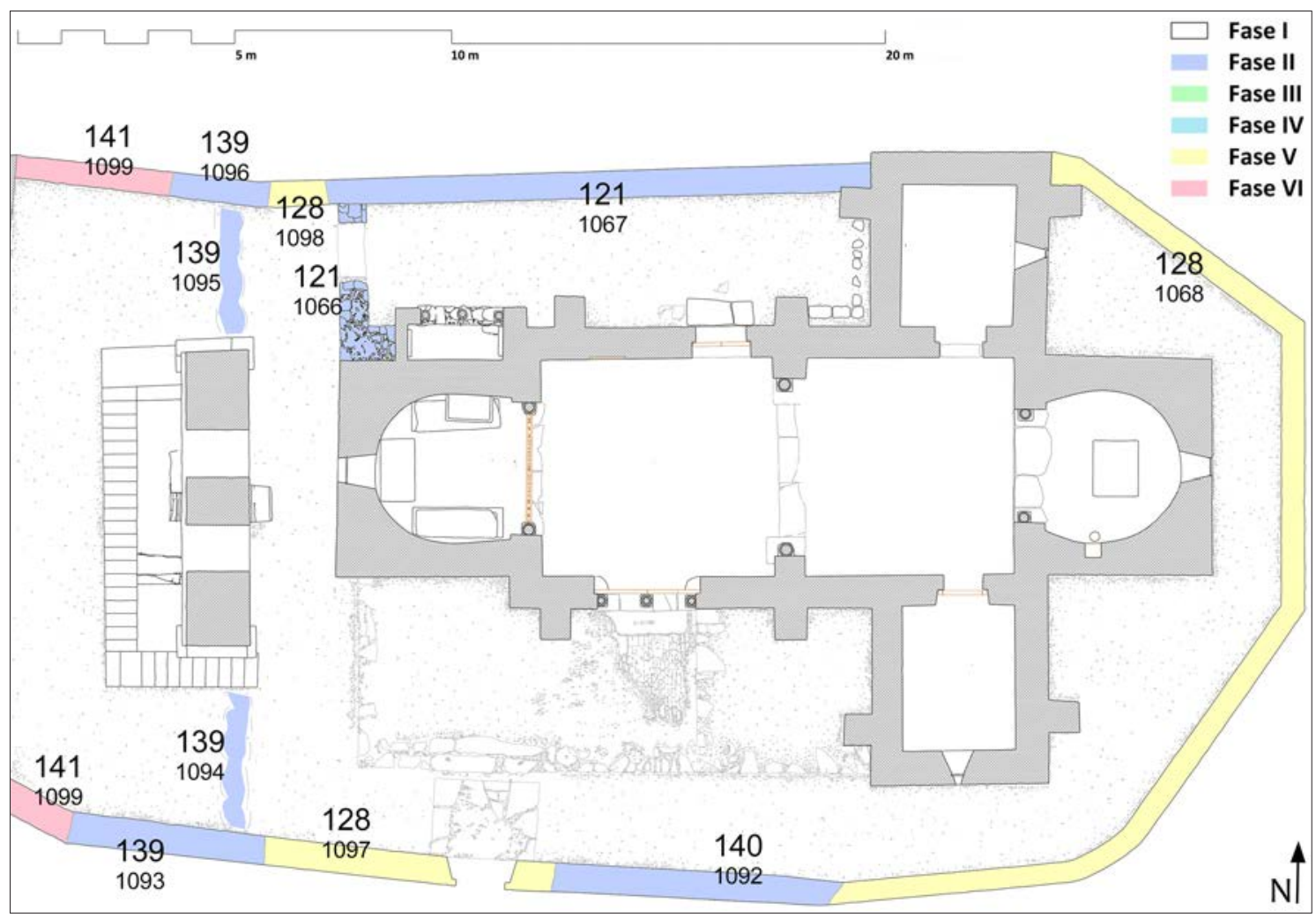

Fig. 1. Planta de la iglesia de Santiago de Peñalba de Santiago con los resultados del análisis estratigráfico de la cerca perimetral

3 Los recursos del proyecto y las características del edificio nos han permitido individualizar en unidades estratigráficas (UE) sus elementos constructivos exteriores y establecer su correlación con los elementos constructivos interiores, estos prácticamente ocultos por una amplia secuencia pictórica que ya fue previamente analizada durante su restauración. La secuencia propuesta por la excavación arqueológica nos ha permitido trabajar sobre un marco estratigráfico previamente definido. El resultado del análisis estratigráfico de las estructuras de la iglesia, sintetizado en actividades (A) y organizado en fases, se ha representado sobre imágenes digitales métricas realizadas por Dogram, las cuales nos fueron facilitadas por el Servicio de Restauración de la Junta de Castilla y León. Acompañamos el texto del correspondiente diagrama y listado de Unidades Estratigráficas y Actividades anexo. 
El grosor de los muros es regular (A 71/73 $\mathrm{cm}$ ) y sus diferentes alturas dotan al edificio de un perfil escalonado. De este modo, la altura del tramo oriental de la nave alcanza $12 \mathrm{~m}$, duplicando su dimensión en planta, y el occidental llega a $9 \mathrm{~m}$, aumentando casi en un tercio la planta. Las habitaciones laterales rondan los $6 \mathrm{~m}$ de altura, correspondiendo de nuevo a uno y medio las medidas de la planta ${ }^{4}$. A excepción del remate del tramo de la navey del ábside occidental, la altura conservada de todos los muros corresponde con la originaria.

Los muros de la iglesia de Santiago se construyen de mampostería de pizarra combinados con piedra caliza en el jambaje de los vanos, las celosías y los modillones. Se emplea además toba para fabricar el arco de descarga de la portada meridional (Fig. 2) y mármol para labrar todas las basas, capiteles y cimacios del edificio. Los fustes también son de mármol, excepto los que sostienen el arco central de la nave que son de granito. En su entorno inmediato, se dan las condiciones para que todos los materiales, excepto el granito (el afloramiento más próximo está en Plutón de Ponferrada), puedan proceder de allí, como ya apuntaba GÓMEZ-MORENO (1919: 227), señalando la gran beta de mármol que recorre al sur esta área ${ }^{5}$.

Las excavaciones arqueológicas han permitido documentar que los muros descendían considerablemente, alcanzando los $3 \mathrm{~m}$ de profundidad, probablemente recurso sobreimpuesto a causa de la evidente inclinación del terreno. El arranque de los muros se efectúa mediante un zócalo de mayor grosor, realizado en mampostería irregular trabada con barro, el cual se sobredimensiona bajo los ángulos y vanos del edificio. Estos cimientos presentan la misma solidaridad constructiva que los alzados de todo el edificio (CORTÉS SANTOS, 2005: 169-171).

Los muros, de doble hoja, se aparejan con lajas de pizarra a lecho, bien acuñadas, en bancos de alturas regulares, que tienden a

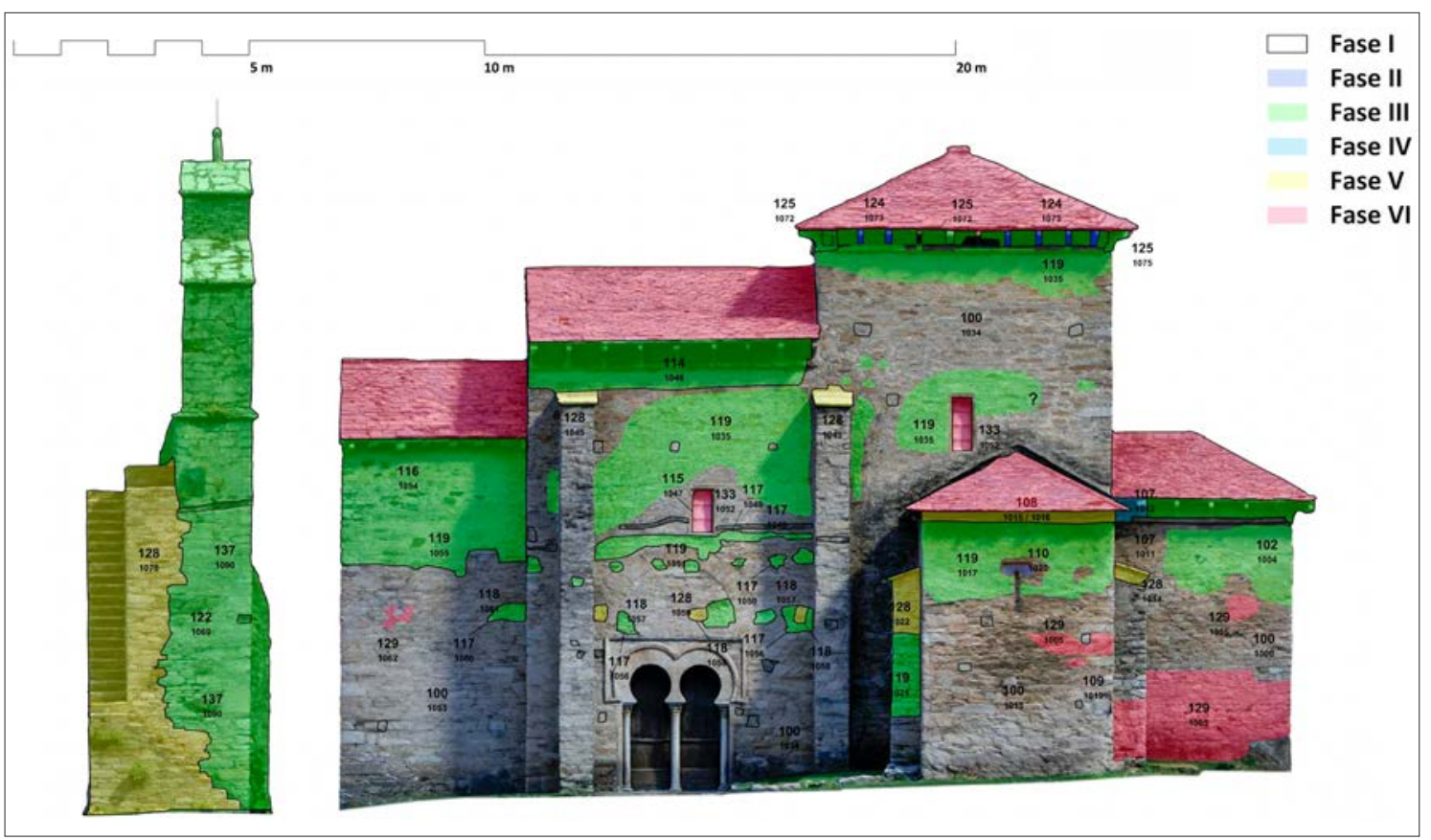

Fig. 2. Alzado sur de la iglesia de Santiago de Peñalba de Santiago con los resultados de su análisis estratigráfico

\footnotetext{
4 Medidas tomadas sobre el pavimento interior e incluyendo el remate de los aleros.

5 Este hecho debería confirmarse con los pertinentes análisis geológicos y petrográficos.
} 
la horizontalidad. Los ángulos de los muros se traban y las esquinas se encadenan con mampuestos ligeramente trabajados y de mayor dimensión (algunas piezas alcanzan los $40 \mathrm{~cm}$ de altura y 95 de longitud). A este ritmo constructivo se alinean mechinales (Fig. 3), no siempre visibles, ocultos por revocos, que permitían anclar al muro y con regularidad los andamios de madera según se alzaban los muros. Concluida la obra, y a medida que los andamios eran desmontados, estos huecos cuadrangulares eran cegados con piezas correctamente adaptadas, trabadas con el mortero propio de la obra originaria.
El mortero que traba la fábrica, elaborado de cal bien batida y con baja proporción de áridos, ofrece una gran dureza. Al asentar los mampuestos en obra, el mortero sobrante que sobresalía irregularmente en los bordes era extendido por el operario con presión, creando así un revoco de superficie tersa y brillante que, sin llegar a ocultar completamente los bloques de piedra, cubría amplias áreas y sellaba y protegía las irregulares juntas. Principalmente, se conservan zonas revocadas con este mortero en la mitad superior de los muros de la nave $y$, en menor medida, en algún rincón de las zonas inferiores (Fig. 4).

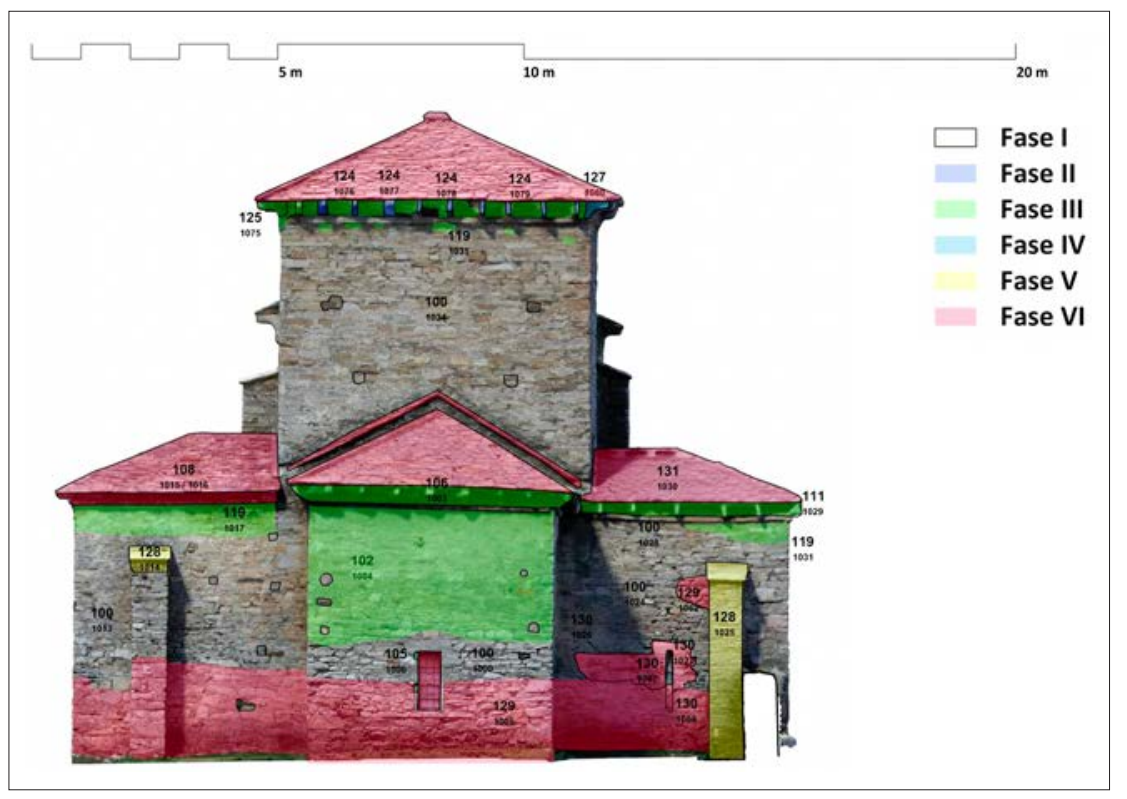

Fig. 3. Alzado este de la iglesia de Santiago de Peñalba de Santiago con los resultados de su análisis estratigráfico

Fig. 4. Restos conservados de revoco originario bajo la cornisa tramo oriental aula y sobre el contrafuerte oeste fachada meridional
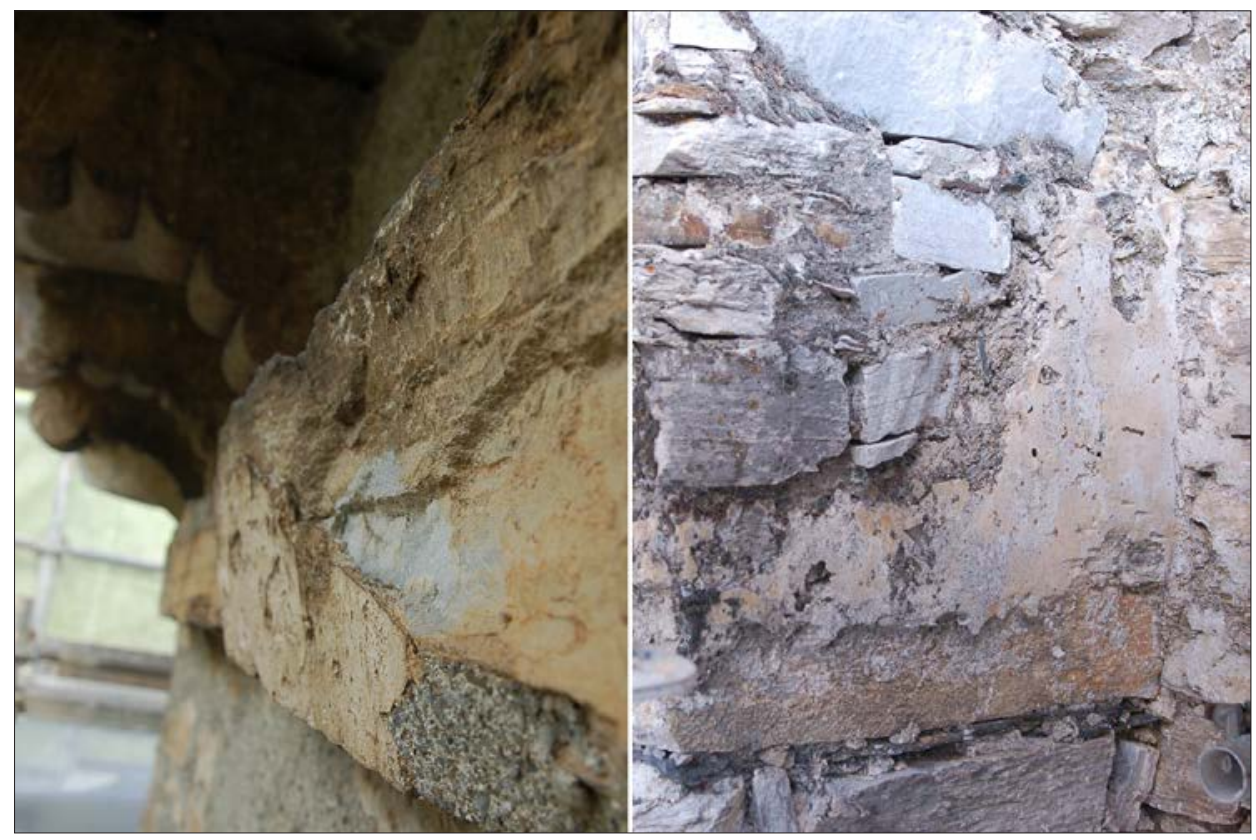
La fachada del ábside oriental presenta dos desagües sobre la bóveda, pieza acanalada que sobresale hasta $4 \mathrm{~cm}$ de la vertical del muro. Una se sitúa en su alzado oriental (Fig. 5) y otra en el septentrional. El mismo sistema se puede observar en los alzados orientales de las habitaciones norte y sur. Estos elementos tenían como función la evacuación de las posibles aguas que se filtrasen desde las cubiertas, para proteger de este modo las bóvedas de las humedades ${ }^{6}$.

El diseño del edificio en planta y altura genera una cadena de cargas que son asumidas por los gruesos muros, bien trabados como hemos indicado en sus encuentros, y por un sistema de parejas de estrechos y altos contrafuertes perfectamente trabados a los muros de la nave y a los de las habitaciones laterales. En las habitaciones laterales, sirven a las bóvedas de cañón dispuestas en eje norte-sur. En la nave, hacen lo propio con la bóveda de cañón que cubre en sentido este-oeste el tramo occidental y con el arco de herradura que diferen- cia los dos tramos. Únicamente los ábsides, con cubiertas gallonadas, prescinden de este tipo de refuerzos, cuya función es asumida por las potentes esquinas generadas por la diferencia de planta al exterior (cuadrada) y al interior (curva) de estos espacios. A su vez, ábside y capillas laterales hacen de grandes contrafuertes de la bóveda gallonada que se alza sobre el tramo oriental (UTRERO, 2006: 510).

Las ventanas de la nave (UE1034) y de los dos ábsides (UE1000 y 1053) son estrechas, altas y de sección abocinada. Poseen las siguientes medidas:

\begin{tabular}{|l|l|l|l|}
\hline Ventanas (exterior) & UE & Alto & Ancho \\
\hline Ábside oriental & 1000 & $1,20 \mathrm{~m}$ & $\begin{array}{l}\text { Exterior: 0,46 m } \\
\text { Interior: 0,74 m }\end{array}$ \\
\hline Ábside occidental & 1053 & $0,85 \mathrm{~m}$ & $\begin{array}{l}\text { Exterior: 0,54 m } \\
\text { Interior; 0,79 m }\end{array}$ \\
\hline Tramo or. nave norte & 1034 & $1,40 \mathrm{~m}$ & $0,40 \mathrm{~m}$ \\
\hline Tramo or. nave sur & 1034 & $1,47 \mathrm{~m}$ & $0,43 \mathrm{~m}$ \\
\hline Tramo occ. nave norte & 1034 & $0,85 \mathrm{~m}$ & $0,42 \mathrm{~m}$ \\
\hline Tramo occ. nave sur & 1034 & $0,93 \mathrm{~m}$ & $0,45 \mathrm{~m}$ \\
\hline
\end{tabular}

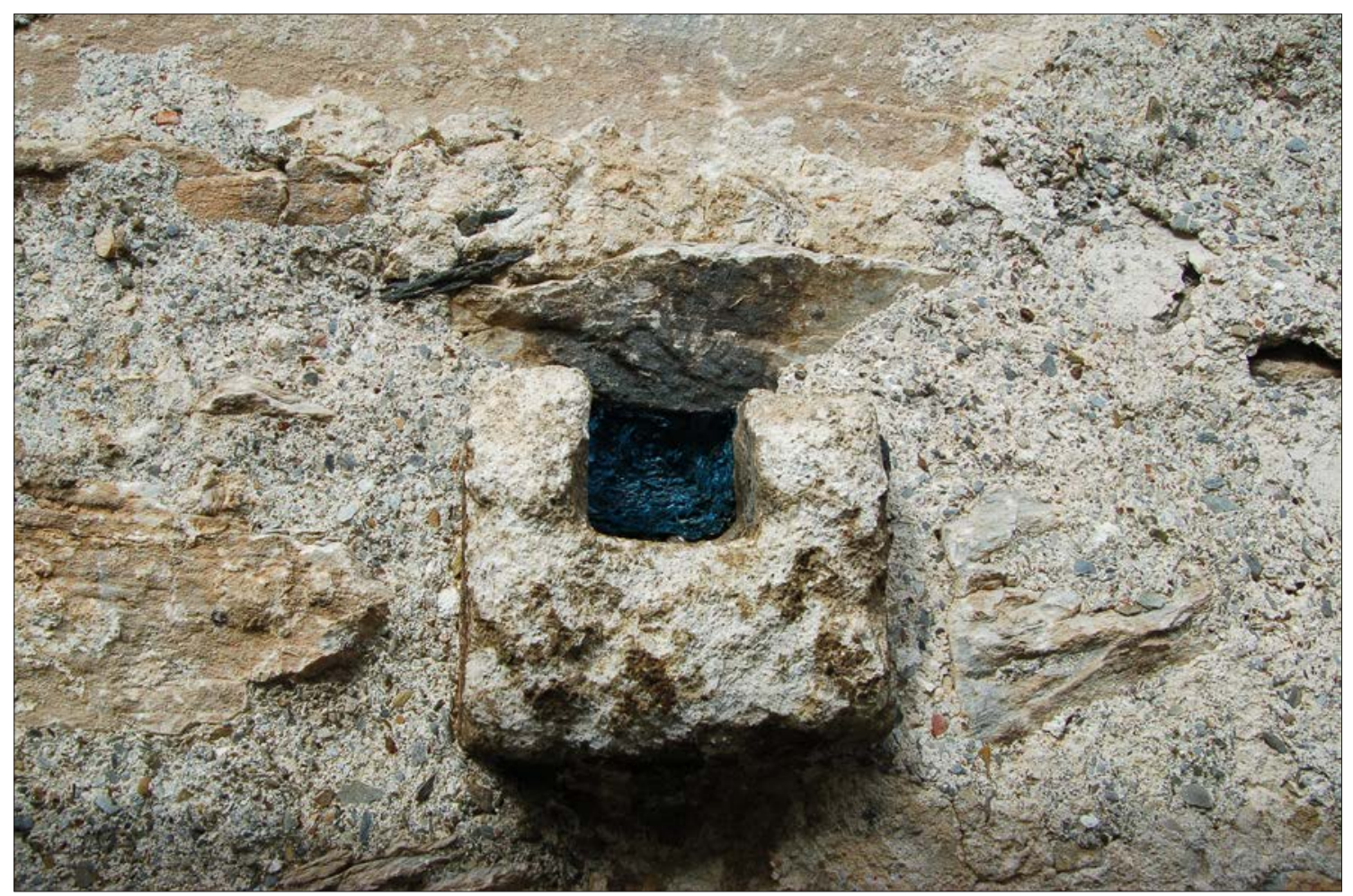

Fig. 5. Desagüe del bajocubierta del ábside oriental

\footnotetext{
6 Estas piezas se documentan en otras iglesias asturianas altomedievales. Así los hace notar Redondo e Ibáñez (1904: 42), quien denomina como bocateja la pieza de Peñalba y la asemeja con las documentadas en Santullano.
} 
El dintel y el umbral de las ventanas se ejecutan con largas piezas de cuarcita, ligeramente trabajadas (Fig. 6). Las jambas se forran con piezas monolíticas de caliza, de entre 6/9 $\mathrm{cm}$ de anchura, en las cuales observamos huellas de hacha. Se anclan al muro con el empleo de alguna pieza horizontal. En el ábside oriental (UE1000), se documenta una pieza de anclaje en forma de "L". Algún dintel conserva restos de una pestaña, con $7 \mathrm{~cm}$ de ancho, la cual actuaba de tope para encajar desde el interior, una vez concluida la obra y antes de desmontar los andamios, las celosías que cerraban las ventanas.

Solo se conserva una celosía, muy deteriorada, situada en el ábside occidental (UE1100). Es una pieza de $0,54 \mathrm{~m}$ de anchura y $0,84 \mathrm{~m}$ de altura (Fig. 7). Dentro de un marco de $4 \mathrm{~cm}$ presenta una decoración vegetal entrelazada y calada, trazada con punzón y tallada a bisel y trépano. Consideramos que la celosía ocupa
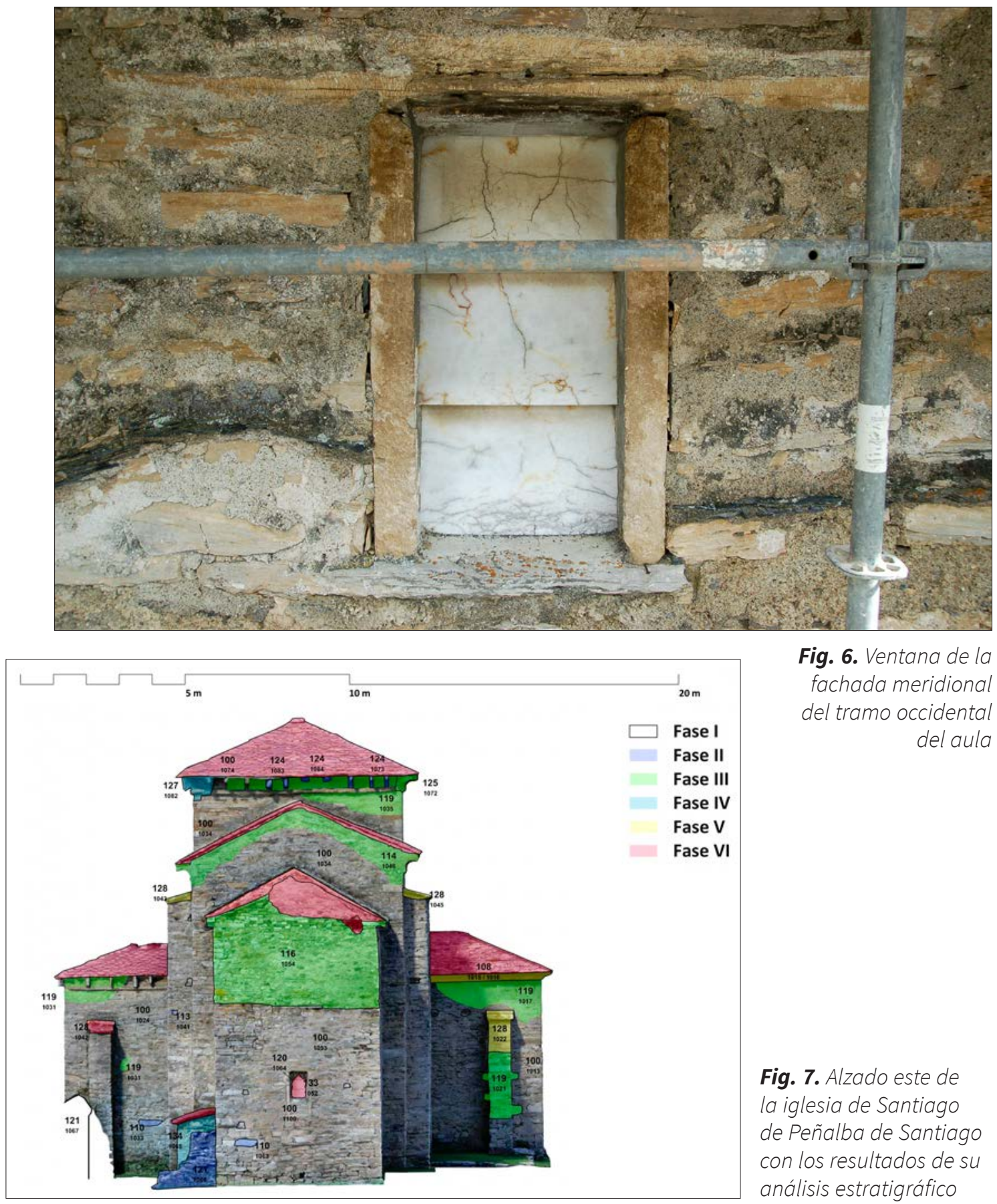

Fig. 6. Ventana de la fachada meridional del tramo occidental del aula

Fig. 7. Alzado este de la iglesia de Santiago de Peñalba de Santiago con los resultados de su análisis estratigráfico 
una posición originaria, sin embargo, el vano donde se inserta fue previamente construido con una luz mayor, de 1,30 m. Esta descompensación se solventó elevando el umbral del vano con un tabique de 0,46 m de altura que para su construcción empleó la mampostería y el mortero propio de la obra originaria. Sin embargo, para rematar el tabique se utilizó un modillón polilobulado colocado de costado. Esta inusual solución podría también interpretarse como el producto de una reforma de la

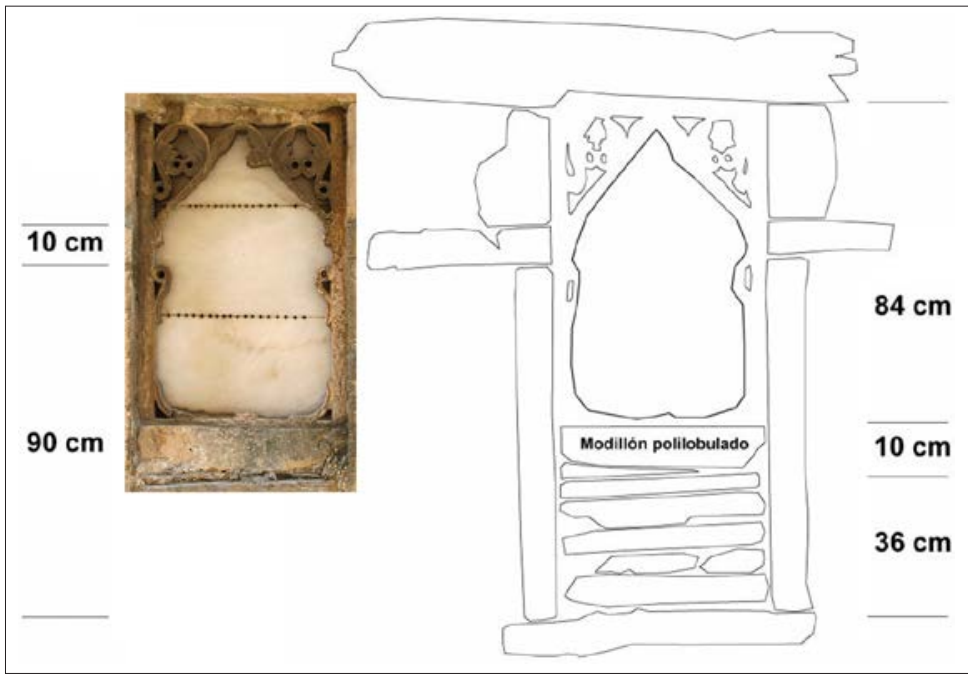

Fig. 8. Ventana de la fachada meridional del tramo occidental del aula fase siguiente. Sin embargo, la anchura de la celosía, coincidente con la del vano originario, no sugiere su reutilización lo que, unido a las características del aparejo y el tipo de mortero empleado, nos conduce a defender que esta actividad formó parte de un replanteo puntual de la obra originaria. (Fig. 8).

Frente a esta homogeneidad en el tipo de ventanas, la habitación sur (UE1013) del tramo oriental de la nave se ilumina con una aspillera, abierta en el muro meridional (Fig. 2). Se compone de un dintel en el que se labra un arquillo tendente a la herradura, sobre el cual se rebajó un entalle recto y rectangular en el frente. A diferencia de la habitación lateral sur, el vano de la habitación norte (UE1024) no es originario y se abre en su muro oriental.

La portada meridional de arcos geminados (UE1034) forma parte del diseño originario de la iglesia, (Fig. 9).

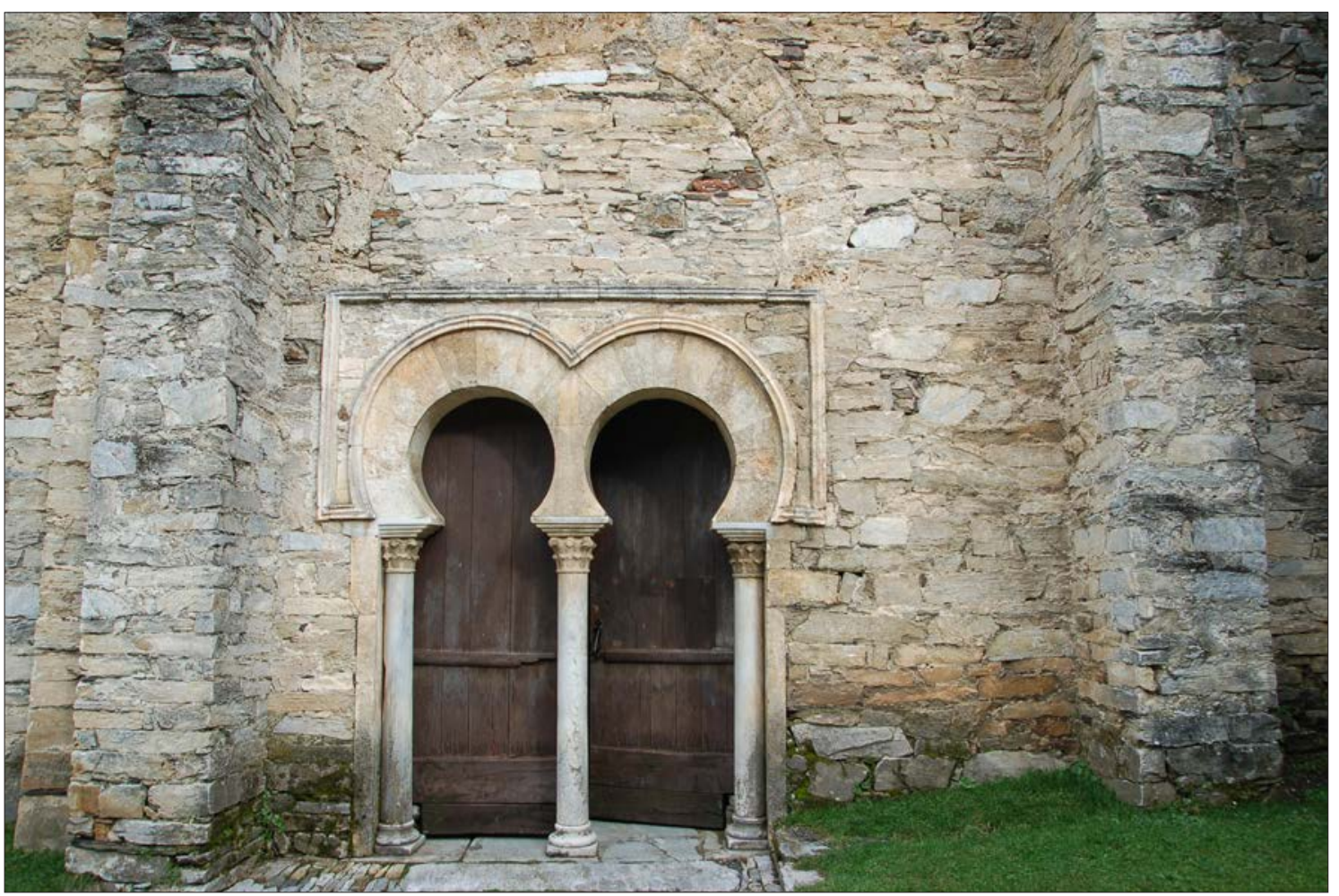

Fig. 9. Portada fachada meridional 
Sus jambas actúan como mocheta y protegen al interior las gorroneras para batientes de puertas, funcionando el soporte central como tope. Este conjunto posee la mitad de dimensión que el muro en el que se abre, actuando el arco de descarga, elaborado en toba, de elemento transición entre la portada y el muro. se montan los arcos y el alfiz sobre ellos. Por último, se alza el "tímpano" de mampostería y el arco de descarga que permiten la continuación de la fábrica del muro. La portada es por tanto un conjunto diseñado en sí mismo y coordinado con el proyecto de la obra.

Al igual que las jambas de las ventanas, las jambas de la portada se componen de piezas verticales de gran altura y de piezas horizontales menores, las cuales se anclan al muro, del mismo modo que lo hacen los cimacios (Fig. 10). Los soportes laterales, compuestos por basas áticas, fustes cilíndricos y capiteles con hojas de acanto, todo ello tallado en mármol, se adosan a las jambas. El diseño y labra de la decoración de los capiteles dejó libre la zona de adosamiento, lo que indica su talla ex profeso para la puerta. Esto no evita aun así que la superficie de la jamba tuviese que ser ligeramente rebajada para un mejor acoplamiento entre las piezas. Se reconocen además guías de ajuste entre los cimacios y los capiteles para obtener un correcto encuadre ${ }^{\text {? }}$. El soporte central es exento y sujeta la dovela común a los dos arcos geminados, los cuales se construyen con dovelas de caliza, pequeñas y bien ajustadas. Son arcos trasdosados, con su pieza de salmer y primera dovela horizontales, rodeados por una moldura a modo de alfiz.

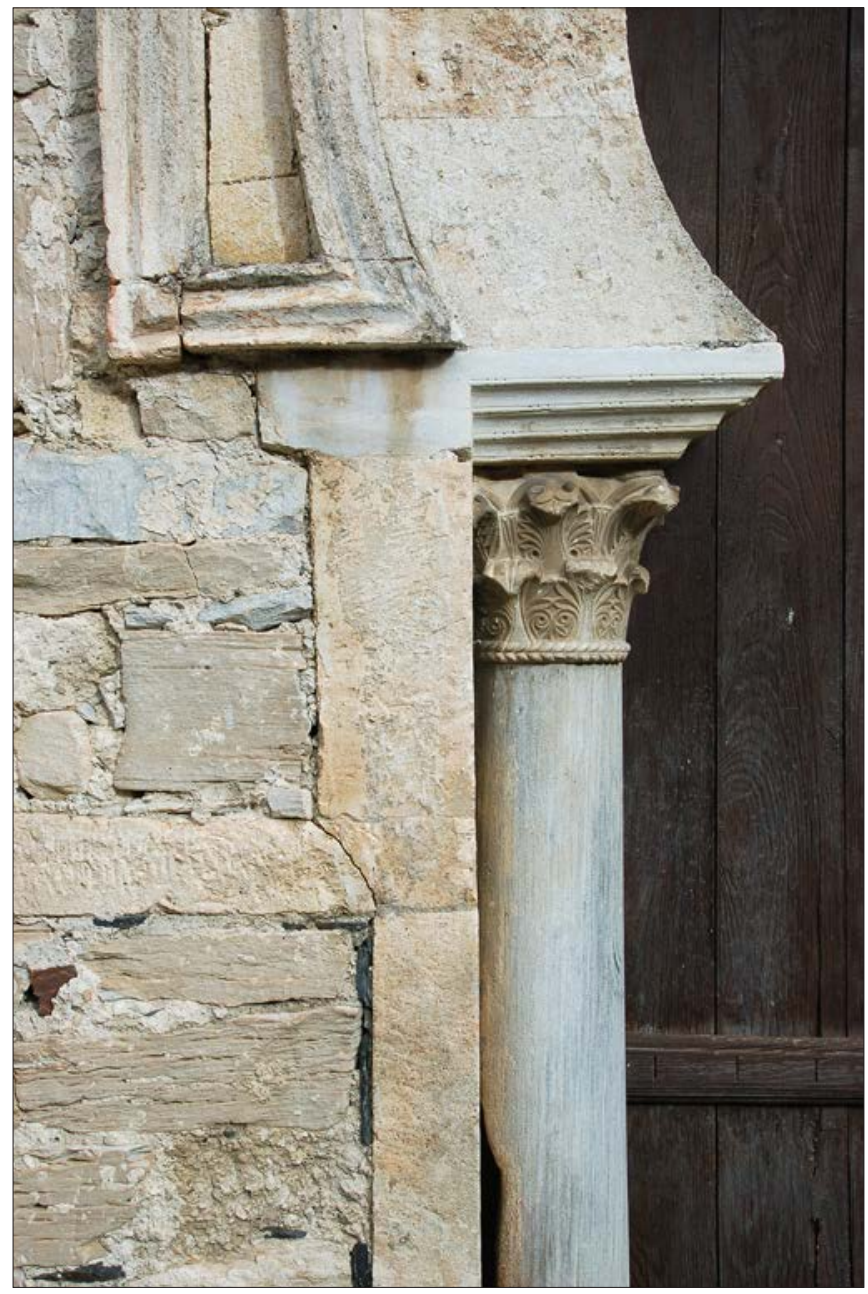

Fig. 10. Anclajes constructivos portada fachada meridional
La portada meridional fue concluida antes de que diera comienzo la construcción del cuerpo superior de la nave y su proceso constructivo es el resultado, por lo tanto, de la siguiente secuencia. Primero se realiza el muro, segundo se introducen las piezas verticales inferiores de las jambas y después las horizontales que sirven de unión con el muro; se introducen los soportes lateral y central y
Existe también una portada norte (UE1034) en el mismo tramo occidental de la nave. No se encuentra enfrentada a la anteriory se abre con un sencillo arco de herradura de dovelas sin trasdosary dimensiones heterogéneas, con la clave ligeramente descentrada. Su jambaje también está formado por piezas verticales y horizontales que se combinan con la mampostería del muro (Fig. 11).

7 Ver imágenes en VILLA, en este mismo monográfico. 


\section{EL INTERIOR DE LA IGLESIA}

El acabado que recubre el interior de los muros y bóvedas de la iglesia y su posterior restauración solo nos permite revisar sus características formales. Los dos tramos de la nave están separados mediante un gran arco de herradura sobre columnas con capiteles corintios. Como ya hemos indicado, el cuerpo oriental es de mayor altura que el occidental. El arco triunfal que da acceso al ábside oriental, está trasdosado con moldura y alfiz, mientras que el del lado occidental carece de éste. El acceso a las capillas laterales desde la nave se efectúa por vanos con arcos de herradura sobre columnas de basas áticas y capiteles con decoración de hojas de acanto que corresponden a la mitad de la dimensión del muro en el que se abre. La otra mitad del muro, al interior de la estancia, se salva con un descargadero de madera (Fig. 12) sobre el que se alza el muro

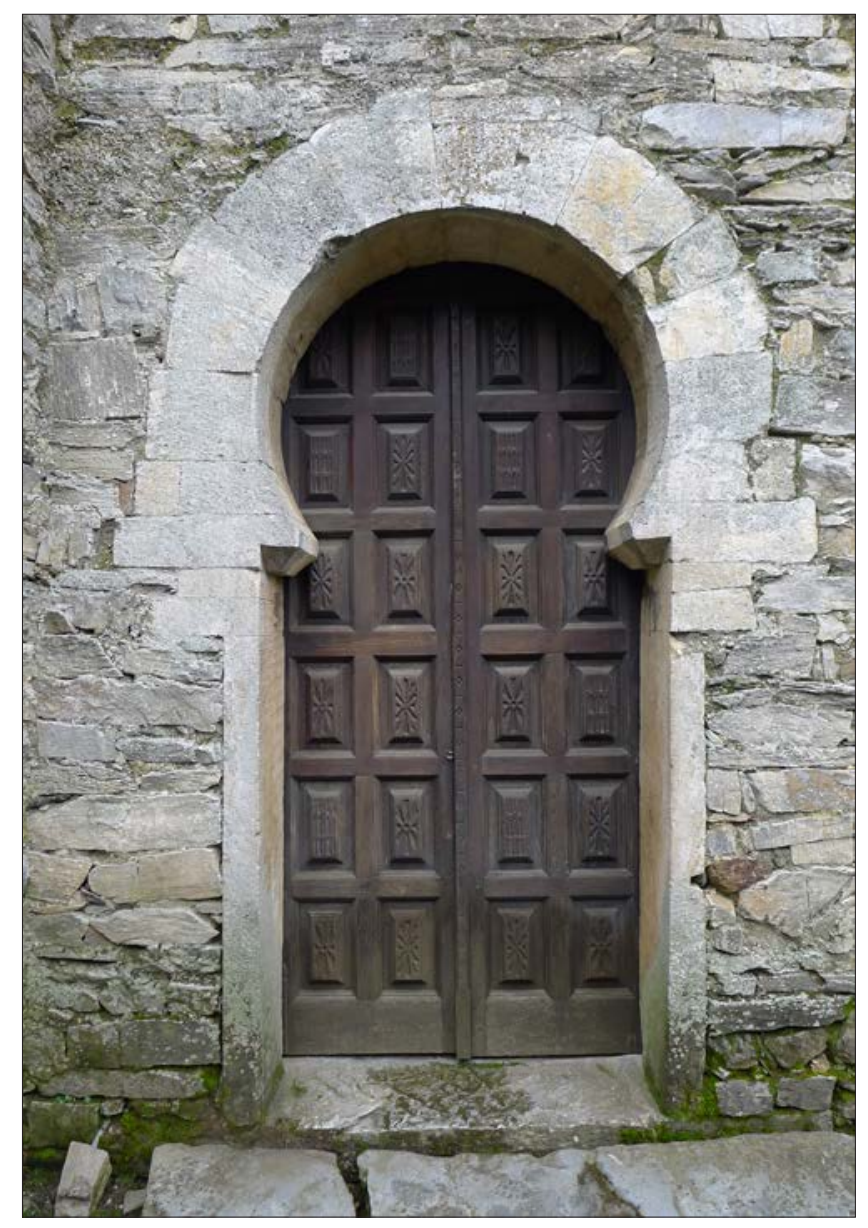

Fig. 11. Portada fachada septentrional

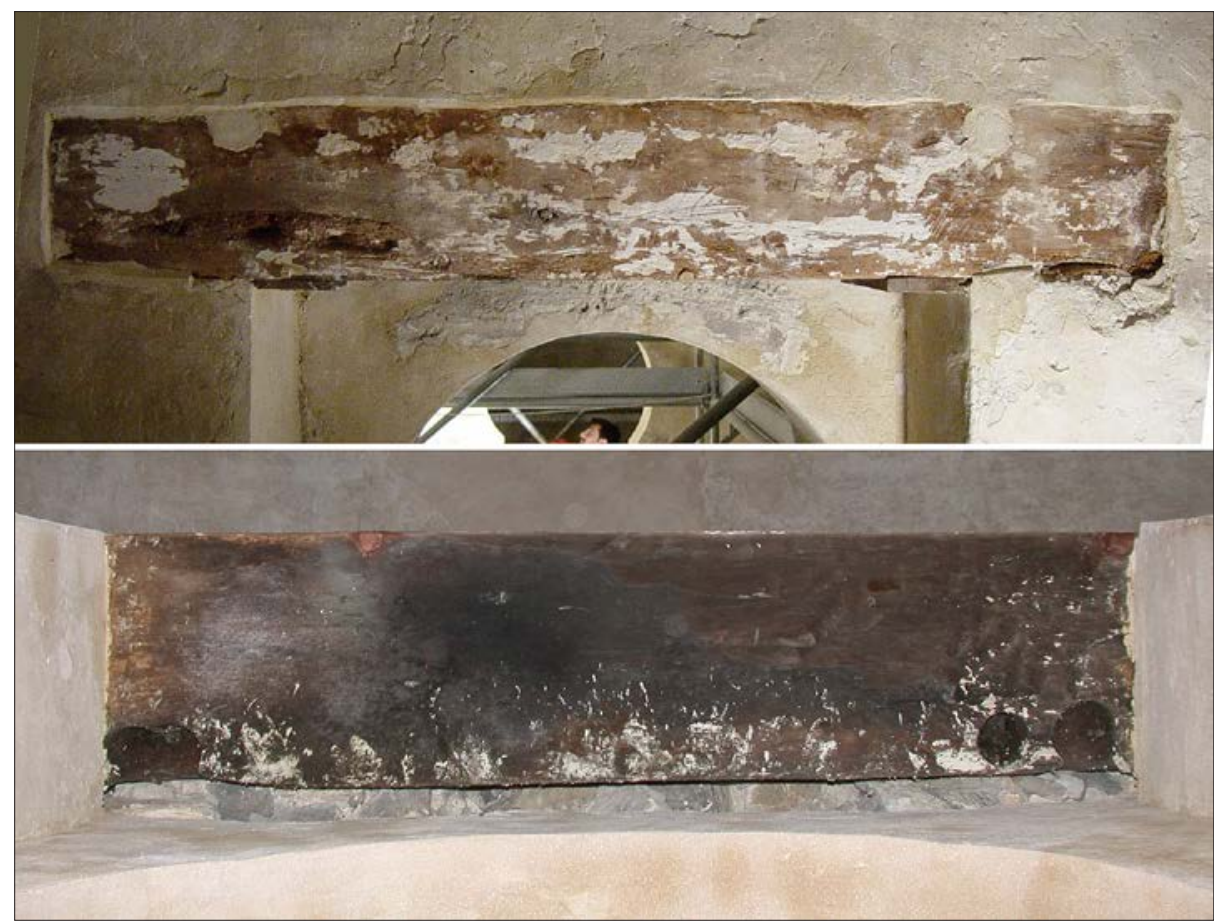

Fig. 12. Descargadero de madera de la puerta de acceso a la habitación sur (arriba), costado vertical, y norte (abajo), base. 
de la nave. Estas piezas presentan gorroneras, para articular el sistema de cierre de la estancia con puertas, en las que se detectan una serie de modificaciones que reflejan su reutilización: la meridional presenta en la tabla del dintel dos parejas de gorroneras, interseccionadas las orientales, secuencia que demuestra que el dintel fue reajustado al ancho del vano; y la septentrional ofrece un juego de gorroneras en el canto, visible al interior de la estancia, que adaptadas en la tabla originaria del dintel a un vano de mayor anchura fueron relegadas a una posición secundaria en el lugar que ahora ocupa (Ver al final del texto Resultado del análisis dendrocronológico).

Los fustes empleados en el interior de la iglesia, mármol en los ábsides, y granito en el arco central de la nave, ofrecen un ensanche central. Esto no ocurre en los fustes del pórtico meridional, de sección cilíndrica. Además, el fuste sur del ábside oriental presenta un rebaje en los extremos superior e inferior para adaptarse a una basa de menor diámetro. Y las dos columnas del ábside occidental emplean dos fragmentos de fustes superpuestos cada una de ellas. Por ello, creemos que los fustes del interior de la iglesia puedan ser piezas reutilizadas, como ya avanzaron al respecto ARBEITER y NOACK-HALEY (1999: 297).

Los ábsides oriental y occidental se cubren con bóvedas gallonadas de siete cascos. El tramo occidental del aula, al igual que las capillas laterales, se cubre con bóveda de medio cañón sobre imposta plana. Y el tramo oriental del aula se cubre con bóveda gallonada de ocho cascos que apoya directamente, sin mediar trompas ni pechinas, sobre cuatro arcos de medio punto ligeramente resaltados. Un pequeño sondeo abierto en el faldón de hormigón armado construido por la restauración del siglo XX (Fase 5) sobre el trasdós de las bóvedas de la nave permitió documentar el uso de piedra caliza (PALOMINO, 2013) para el dovelaje de pequeñas lajas originario, que se empleó para construir todas las bóvedas del edificio
(ITO, 2012: nota 24), y no, como se había propuesto previamente, de ladrillo (UTRERO, 2006: 160, 510). Sin embargo, las dovelas de los arcos que sostienen las bóvedas son de tipo tobaceo (ITO, 2012: nota 24), como las del arco de descarga que ya se ha descrito sobre la portada meridional.

Los muros interiores, sus arcos y las bóvedas ofrecen restos de un acabado terso sobre una base de mortero de cal y baja proporción de áridos de similares características al descrito al exterior. Esta superficie originaria se decoró al fresco con pinturas de tonos ocres y azules, aplicadas sobre un trazado previo realizado con punzón y el apoyo de la regla y el compás, la cual recrea composiciones geométricas clásicas, otras vegetales y ladrillos fingidos. Los restos de pinturas originarias conservadas se distribuyen sobre los arcos y las bóvedas de la nave y ábsides. Los zócalos se acabaron a la almagra, con un óxido de hierro arcilloso.

La composición decorativa originaria quedó oculta por hasta siete superposiciones de diferente índole (Fig. 13): pintura mural y lechadas de cal, documentadas de manera precisa por los últimos trabajos de restauración (TEJEDOR, SUÁREZ-INCLÁN, 2006).

Los sondeos arqueológicos han permitido documentar que los suelos, unitarios y originales, se echan una vez acabados los muros, sobre los cuales se adosan. Se trata de pavimentos de mortero dispuestos sobre una preparación de pequeñas piedras de esquisto y pizarra hincadas a $45^{\circ}$. Su construcción es sincrónica a la instalación de los sepulcros de lajas de pizarra que se sitúan en el ábside oriental, los únicos enterramientos documentados al interior de la iglesia, atribuidos a los Santos Genadio y Urbano.

Las basas del arco central de la nave presentan sendos huecos enfrentados, quizá el anclaje de los característicos canceles de este periodo, sin embargo no se localizan ni en los fustes ni en el pavimento inmediato huellas o entalles asociados. 

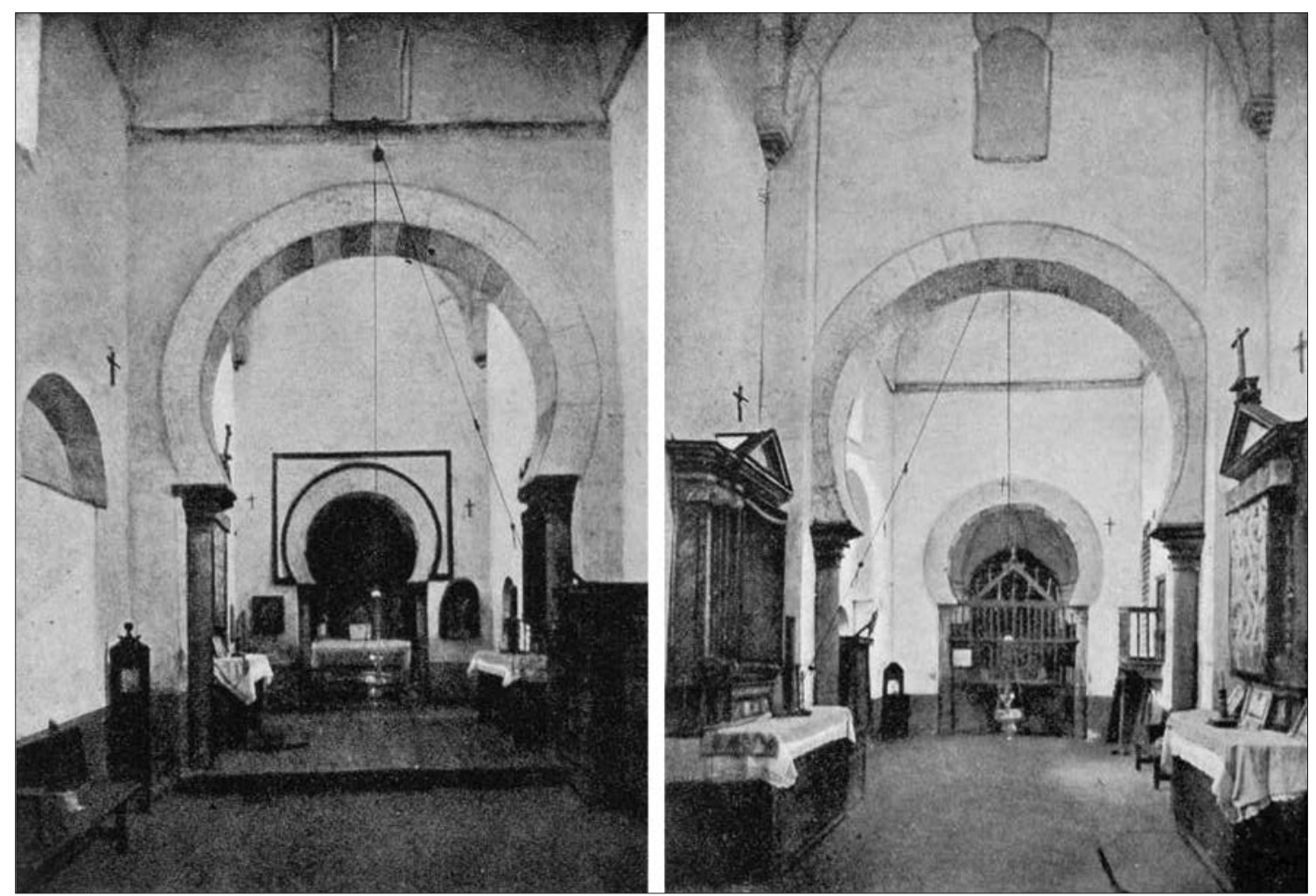

Fig. 13. Vistas del interior de la iglesia hacia el este y el oeste con la superficie de sus muros encaladas (GÓMEZ-MORENO, 1925: Fig. 48-49)

\section{ALEROS DE MODILLONES POLILOBULADOS}

La cubierta del edificio se proyecta sobre un amplio alero de canes de diversas tipologías, que próximos unos a otros, se asientan sobre una moldura prismática. Esta es originaria en el tramo oriental de la nave, en el ábside oriental y en la habitación norte (UE1000 1024 1034). Se compone de largas piezas escasamente trabajadas, las cuales sobresales del muro entorno a los $10 \mathrm{~cm}$.

Los canes que se emplean en la fase originaria son modillones polilobulados (Fig. 14). Estos presentan un desarrollo con seis o siete baquetones, el superior o exterior con el doble de diámetro. Los costados de los baquetones tienden a estar completamente decorados con esquemas circulares secantes de flores hexapétalas y hélices y el ángulo superior de su encuentro rebajado. Sobre esta decoración se tallan tres trazos picudos, a modo de cuernos (Fig. 15).
Los modillones polilobulados de Santiago muestran peculiaridades propias del grupo leonés, como son la talla realizada a bisel y el lóbulo superior de mayor tamaño. Al igual que ocurre en Escalada, Mazote y Palat (TORRES BALBÁS, 1936: 256; ver Villa en este mismo monográfico), las decoraciones de las caras laterales presentan hélices, hexapétalas y trazos picudos. Sin embargo, los modillones de Santiago ofrecen un acabado desigual, que va desde aquellos en los cuales solo se le ha trazado a punzón la decoración (Fig. 16), hasta los que ofrecen el acabado completo (Fig. 15), pasando por estados intermedios de acabado (Figs. 14 y 17). Existe algún caso en el cual tan solo fue trabajado un lateral. La cadena de baquetones menores secantes se traza inserta en un círculo secante mayor y la labra de su decoración siempre comienza desde el superior de mayor tamaño. Este siempre se decora con una hélice y los menores con hexapétalas, aunque esta regla no se cumple en los modillones polilobulados del ábside oriental, 
donde se observa el empleo combinado de octopétalas con hélices (A100, UE1006: modillones número 68, 70, 75 y 76 y 79; Fase 3, Fig. 18). Finalmente, solo son rematados con trazos picudos a modo de cuernos aquellos que presentan todos los lóbulos decorados y sus ángulos superiores rebajados, a modo de detalle final (Fig. 15).

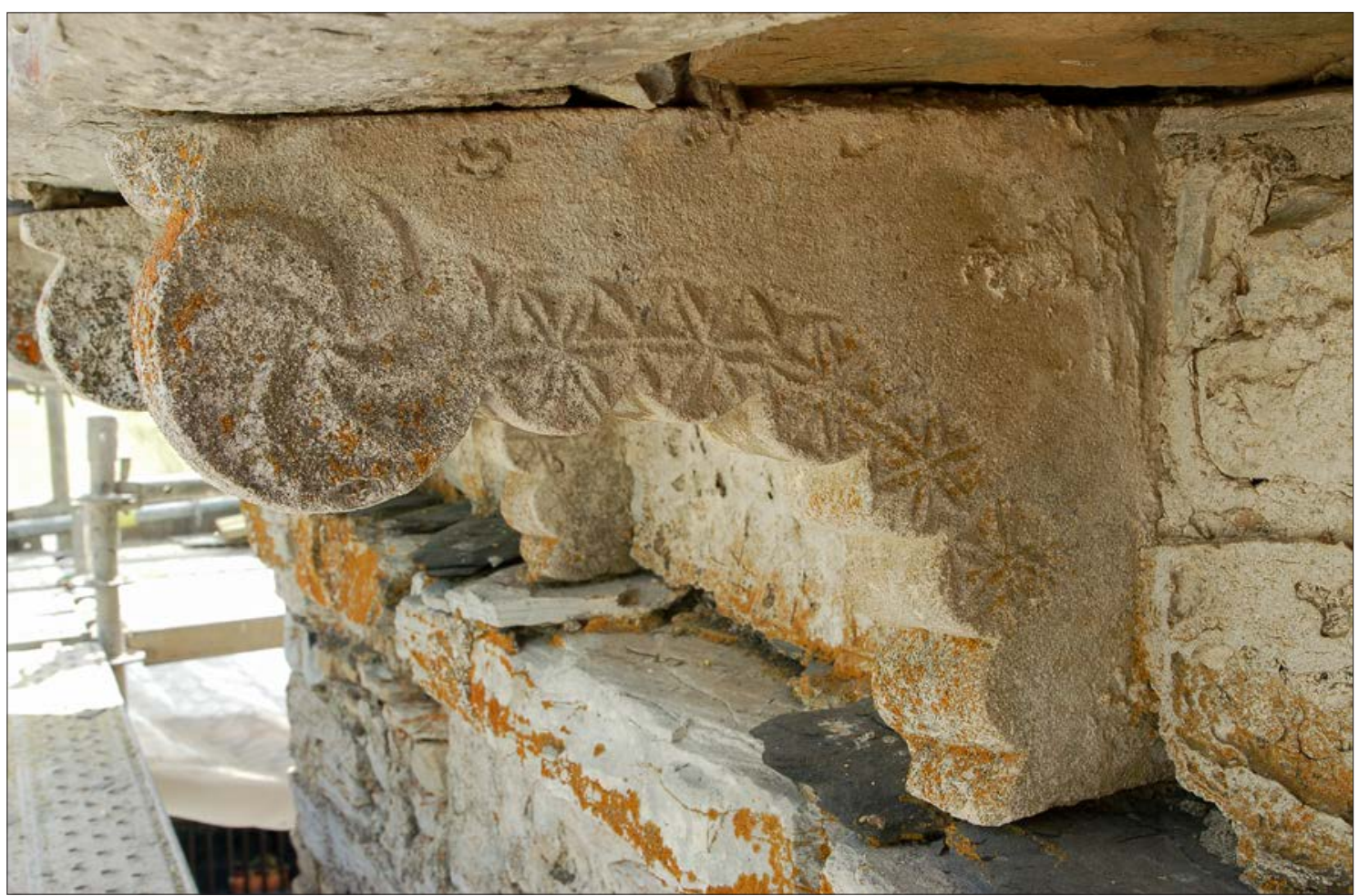

Fig. 14. Modillón polilobulado del alero del tramo oriental aula correspondiente a la fase 1 (A100, UE1074: Modillón número 27)

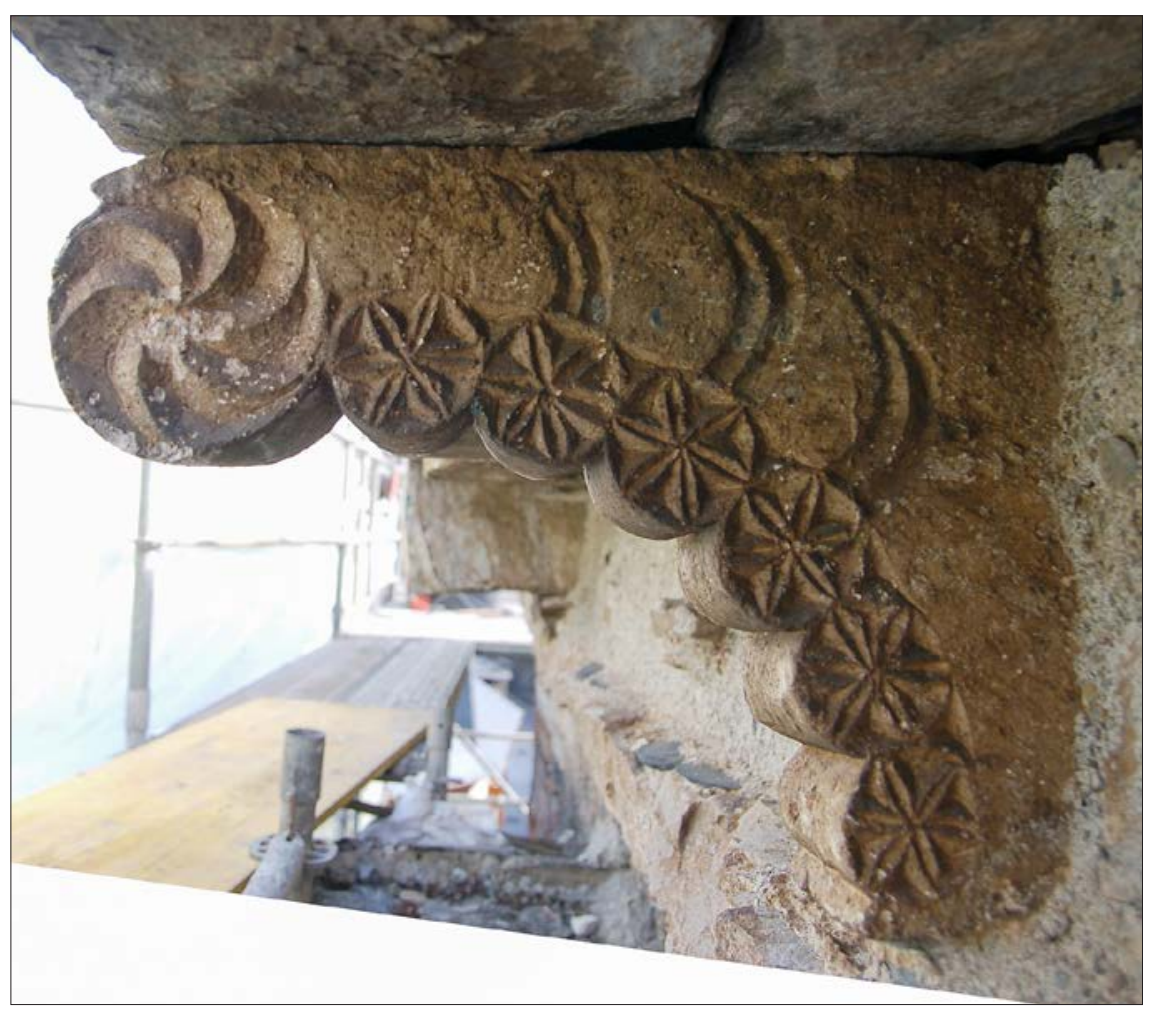

Fig. 15. Modillón polilobulado del alero del tramo oriental aula en el que se reconocen todas sus características pero que corresponde a la fase 2 (A124, UE1073: Modillón número 11) 


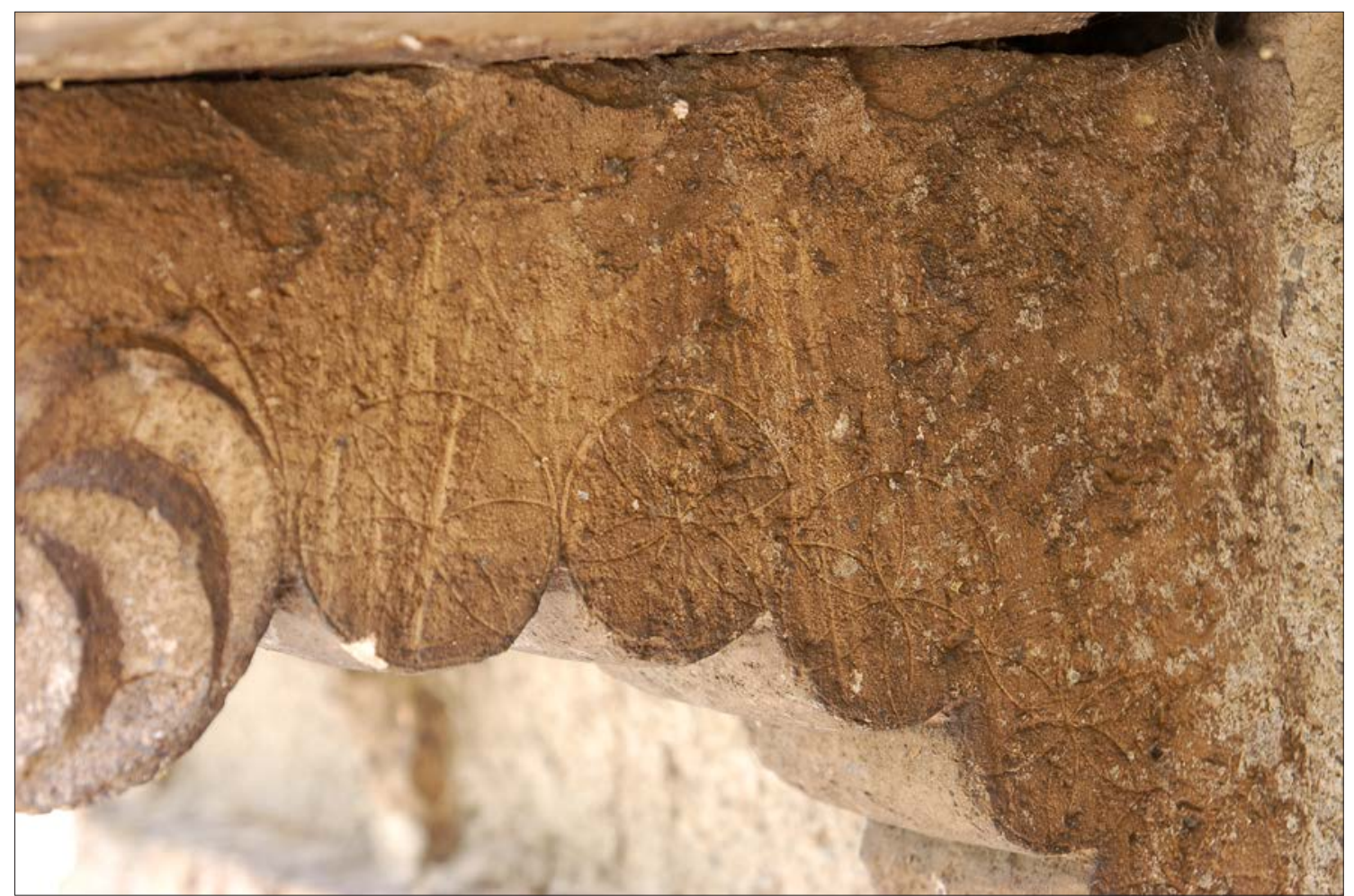

Fig. 16. Modillón polilobulado del alero del tramo oriental del aula donde reconocemos la traza a punzón de su esquema decorativo sin acabar correspondiente a la fase 2 (A124, UE1073: Modillón número 4)

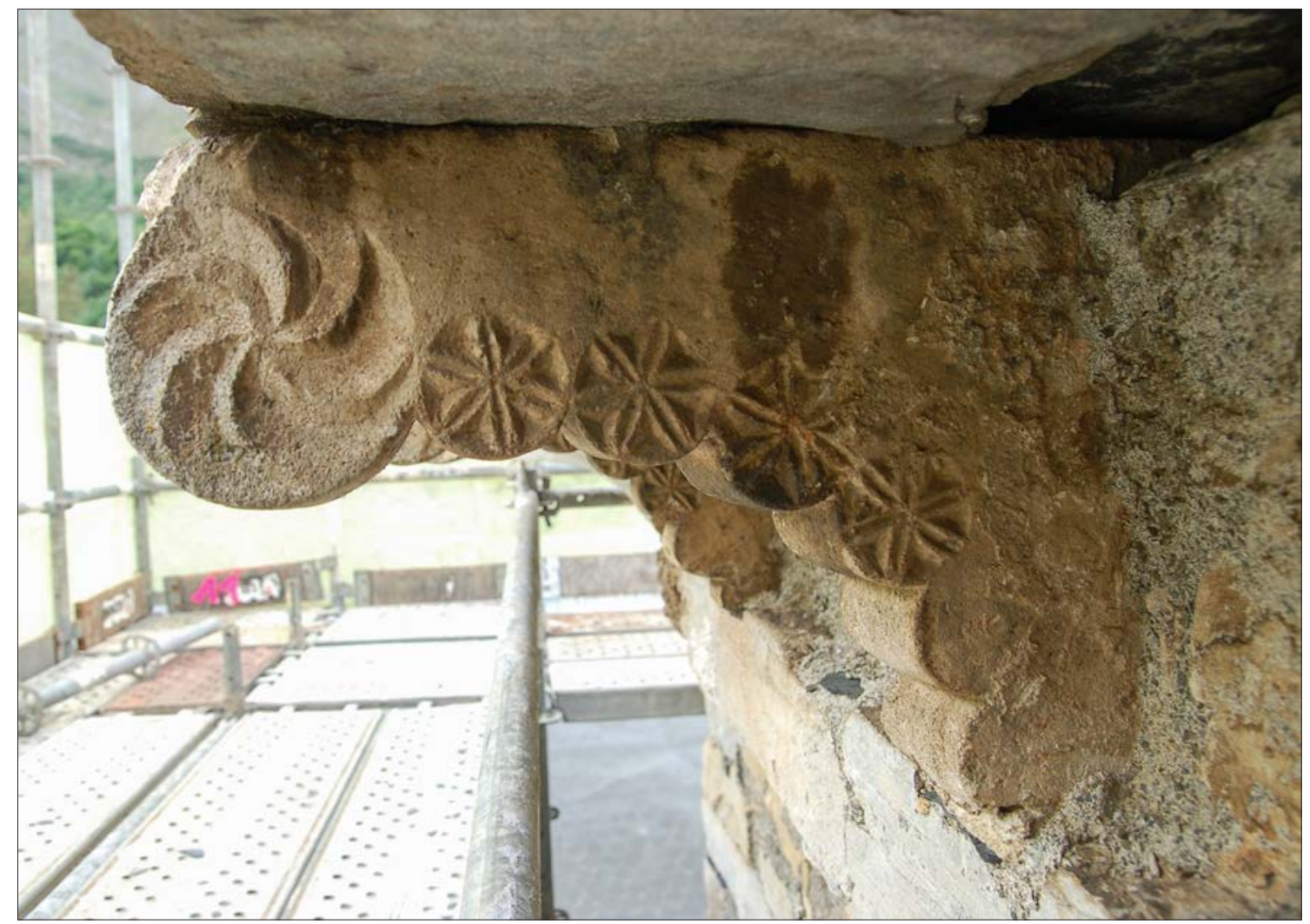

Fig. 17. Modillón polilobulado del alero del tramo oriental del aula con la decoración de los últimos modillones sin acabar correspondiente a la fase 2 (A124, UE1076: Modillón número 15) 


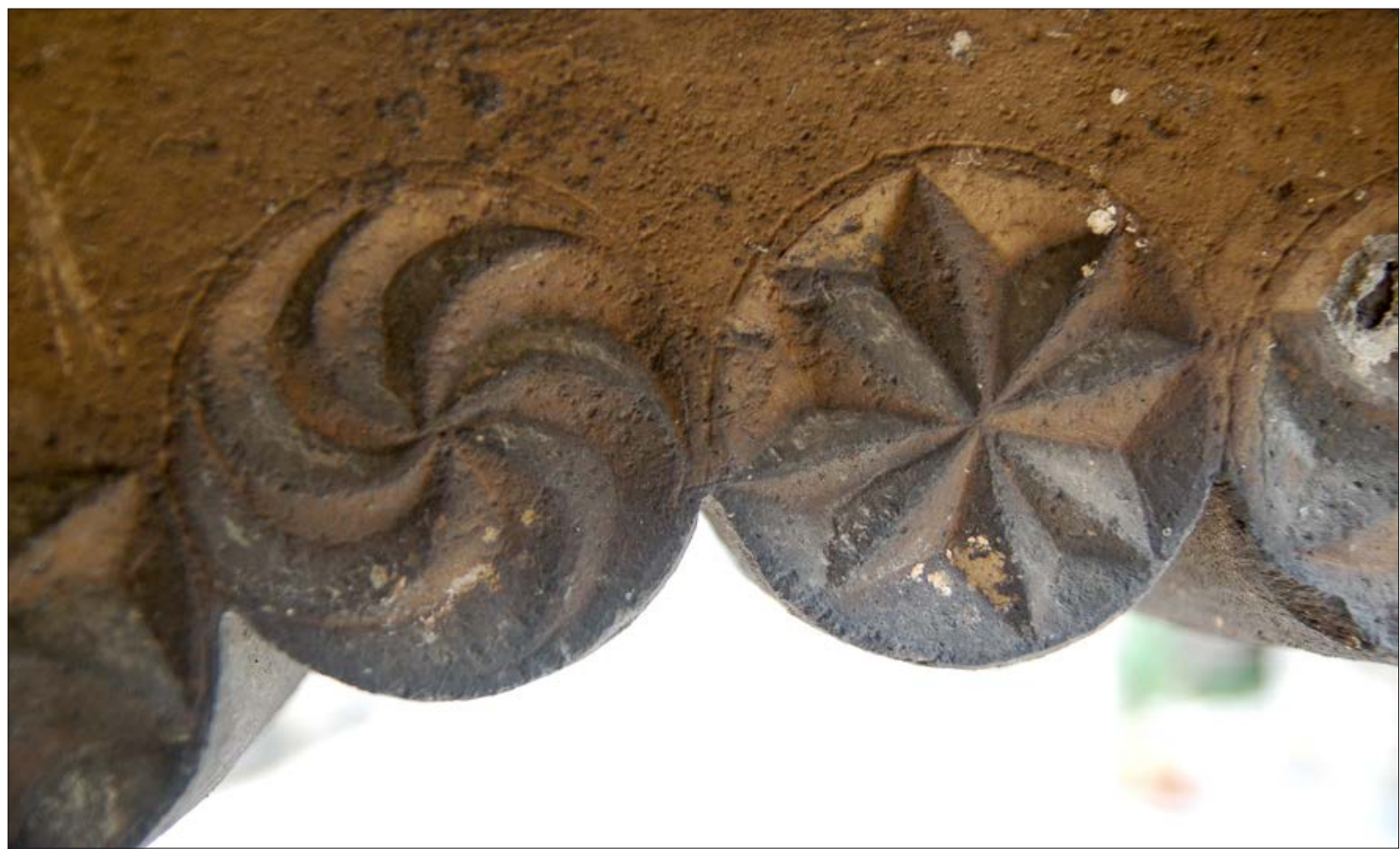

Fig. 18. Detalle del modillón polilobulado del alero del ábside oriental donde se combinan octopétalas y hélices pero que corresponde a la fase 3 (A100, UE1006: Modillón número 68)

Santiago de Peñalba es la iglesia del grupo mozárabe tradicional (GÓMEZ-MORENO, 1919) que mayor número de modillones polilobulados conserva en el edificio, aunque no todos ocupan su posición primaria. En total son 35 modillones polilobulados distribuidos por los diferentes aleros de la iglesia, de los cuales tan solo 9 podemos considerar como situados en su posición originaria. De los 23 conservados en el alero del tramo oriental de la nave, 7 (Fig. 19) se traban con el mortero propio de la obra originaria (UE1074: modillones número 5, 7, 26, 27, 29, 36 y 37$) ; y$ de los 4 conservados en los aleros del tramo occidental de la nave, 2 se traban constructivamente con el cuerpo alto del tramo oriental de la nave (UE1034: modillones número 45 y 62). No podemos decir lo mismo de ninguno de los 8 modillones polilobulados situados en el

Fig. 19. Esquema de distribución de los canes del alero del tramo oriental del aula alero del ábside oriental (Fig. 20). Y como ya avanzamos en el primer apartado de esta fase, otro modillón polilobulado fue empleado como umbral de la ventana del ábside occidental, desechado y reutilizado durante la etapa de construcción de la iglesia (Fig. 8).

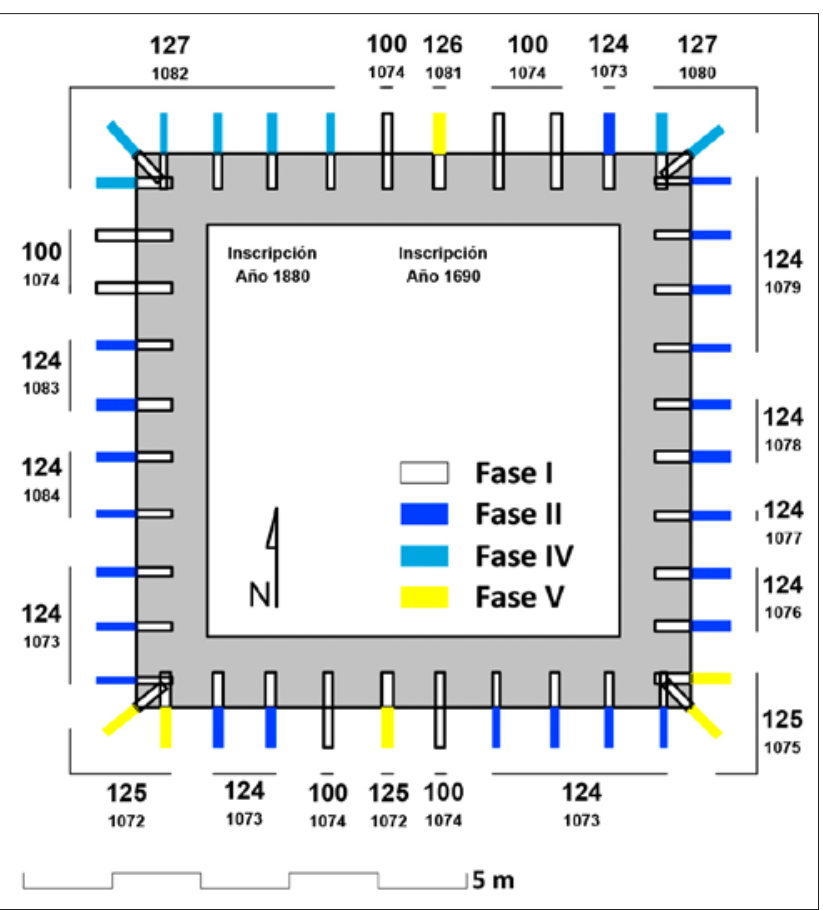




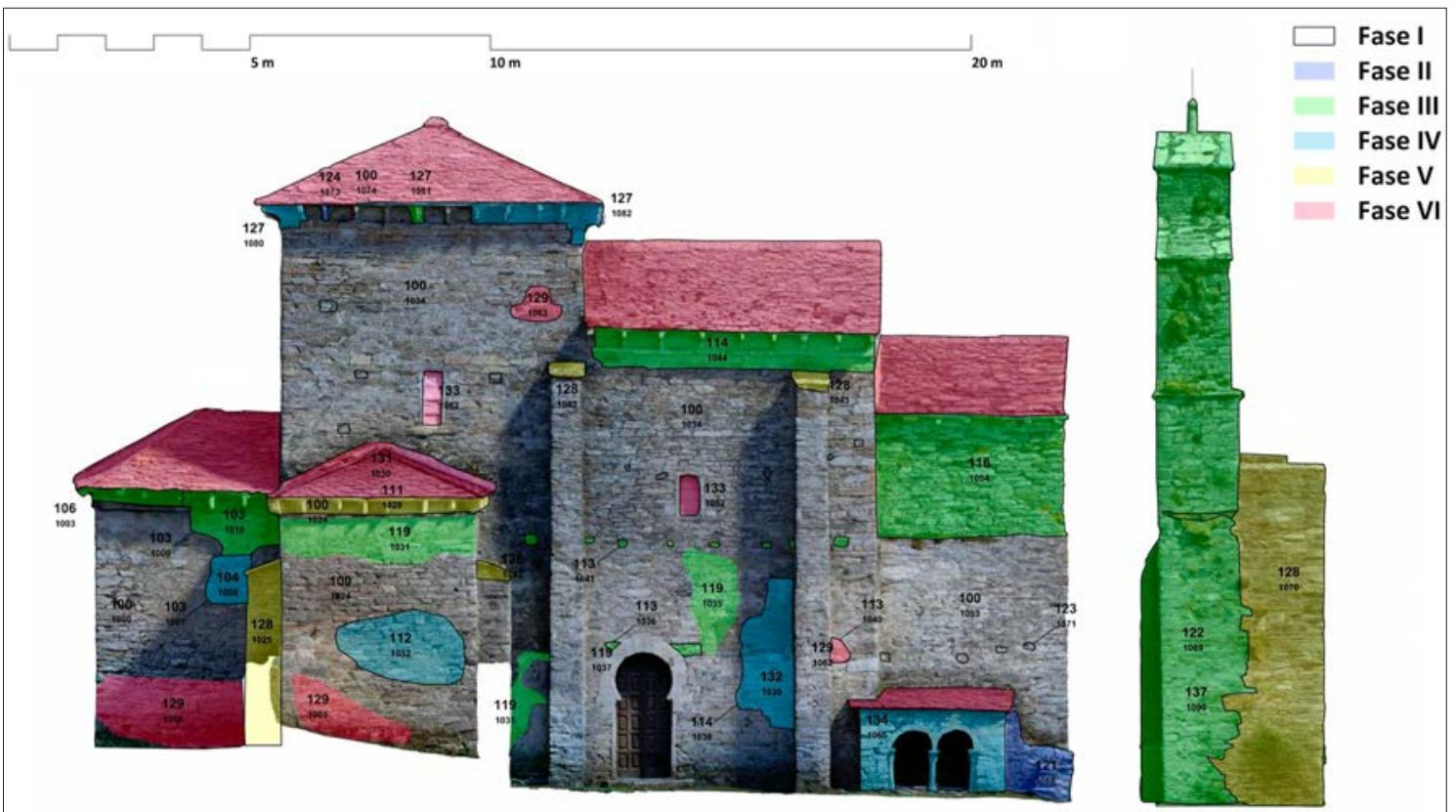

Fig. 20. Alzado norte de la iglesia de Santiago de Peñalba de Santiago con los resultados de su análisis estratigráfico

Los otros 16 modillones polilobulados que se reparten por los cuatro aleros del tramo oriental de la nave (UE1073: modiIlones número 3, 4, 8, 9, 10, 11, 25, 42, 43 y 44; UE1074: modillones número 36 y 37; UE 1076: modillones número 14 y 15; UE1082: modillones número 32 y 35) y los 9 del ábside oriental (UE1003: modillones número 67, 68, $69,70,71,75,76,78$ y 79) consideramos que no ocupan su posición originaria (Fig. 21). Los principales argumentos para afirmar que han sido reubicados por las sucesivas obras de mantenimiento de la cubierta son, por un lado, la presencia de roturas, cuñas y cajeados en la imposta sobre la cual se asientan, y por otro, la existencia de reformas en los espacios de fachada entre modillones. La ausencia de enfoscado originario en estos espacios intermedios es un argumento más para dudar acerca de si los modillones ocupan su posición originaria. Se conservan algunos fragmentos de este tipo de canes en el museo de León, como los empleados como orejetas de cistas funerarias de periodos avanzados hallados durante las excavaciones arqueológicas (CORTÉS SANTOS, 2005: 193).

\section{Fase 1b. Estancias adosadas a la iglesia originaria}

A101, UE1001 1002; A109, UE1019; A113, UE1036 1040 1041; A117, UE1048 10491050 1056 1060; A123, UE1071

La excavación arqueológica pudo reconocer, adosados sobre las fachadas norte y sur de la nave y del ábside occidental, sendos pavimentos de mortero sobre una base de piedras hincadas de idénticas características al empleado en el interior de la iglesia. El suelo situado al sur se pone en relación con una serie de estructuras que delimitan una estancia rectangular también adosada a la iglesia, con una anchura menor que la habitación sur. El pavimento situado al norte sella un cementerio de cistas de lajas de características altomedievales. Las afecciones posteriores que estos elementos presentan permiten a CORTÉS SANTOS (2005: 183-186) adscribirlos a un momento inmediato a la construcción de la iglesia, interpretándolos como posibles pórticos; aunque en el caso septentrional, también podría tratarse de un cementerio monástico. Ambas estructuras se asocian con las huellas sobre las fachadas a las que se adosan, las cuales 


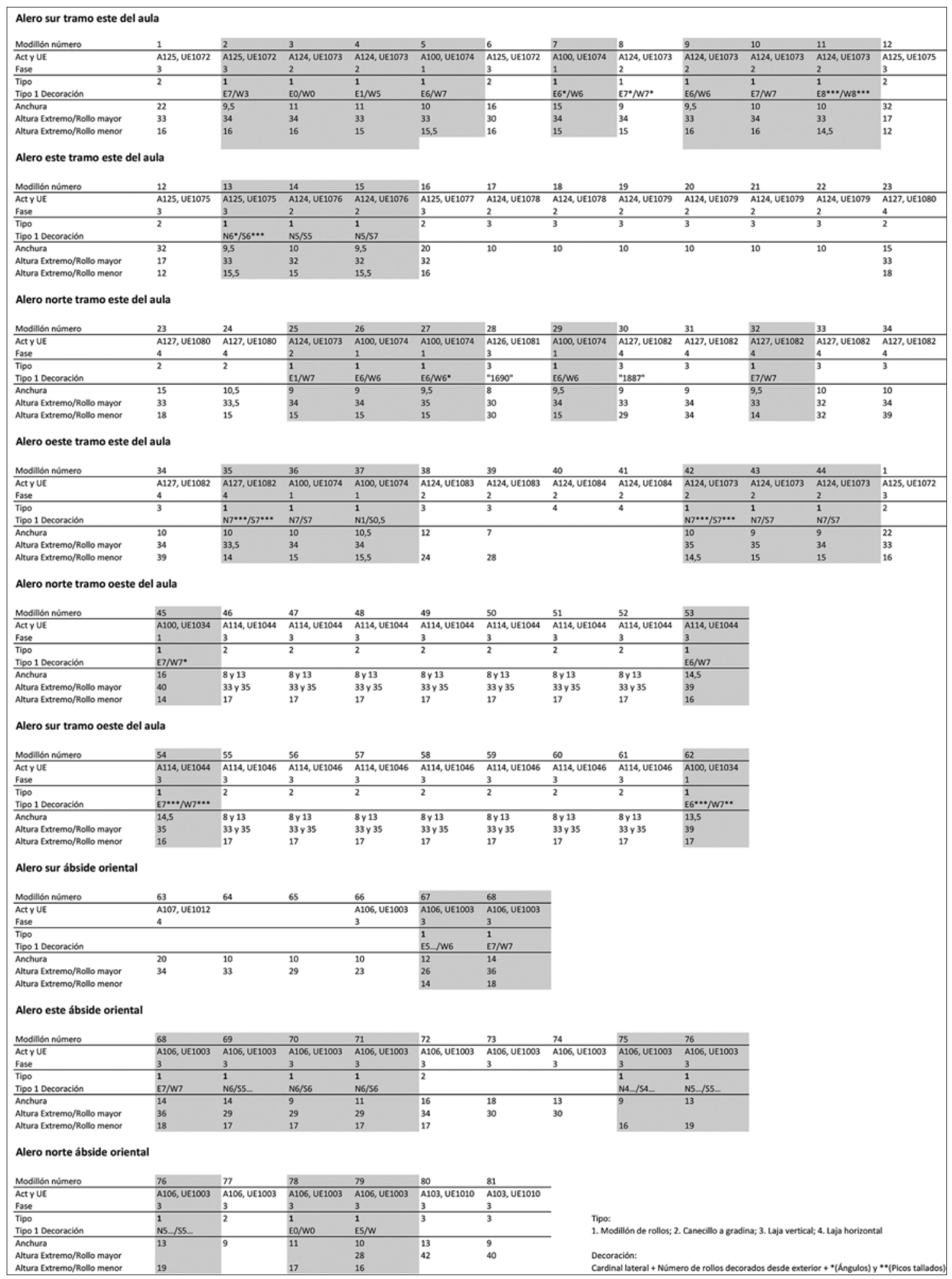

Fig. 21. Tabla descriptiva de los canes de los aleros de los dos tramos del aula y del ábside oriental

podrían corresponder a sus cubiertas. Al pórtico septentrional (Fig. 20) pertenecerían dos series horizontales de agujeros, una inferior que reconocemos a ambos lados del arco de la puerta norte (A136, UE1036 1040) y que con- tinúa sobre la fachada del ábside occidental (A123, UE1071), y a una altura mayor, antes de alcanzar la ventana norte del tramo oeste del aula, otra serie de agujeros (A113, UE1041) que coinciden con el nivel del ábside occidental, 
sobre el cual se superpondrá un nuevo cuerpo constructivo más adelante. Al pórtico sur (Fig. 2) corresponderían dos series horizontales de agujeros (A117, UE1050 1056 1060) distribuidos entre los dos contrafuertes a ambos lados de la portada y unas rozas con restos de pizarra (A117, UE1048 1049) que existen sobre los anteriores. Sobre la fachada oriental de la cabecera, localizamos otros agujeros (A101, UE1001 1002) que también podrían corresponder a una edificación adosada. La misma circunstancia se produce sobre la fachada sur de la habitación sur (A109, UE1019).

\section{Fase 2. Usos cementeriales, edifica- ciones perimetrales y reparaciones en el alero del aula. Amplio periodo de reformas que discurren desde el medievo hasta época moderna}

A110, UE1020 10331063 1085; A121, UE1066 1067; A124, 10731076107810791083 1084; A139, UE1093 10941095 1096; A140, UE1092

La siguiente fase incluye un conjunto de actividades que no pueden ser secuenciadas entre ellas por la ausencia de relaciones estratigráficas directas, de rasgos tipológicos de cronologías precisas o referencias documentales explicitas. No son coetáneas entre sí, pero podemos asegurar su posterioridad al edifico originario y la anterioridad a elementos propios del periodo barroco.

La ampliación del primer uso cementerial alrededor de la iglesia documentado por la excavación arqueológica lleva asociada una serie de inscripciones grabadas sobre los muros de la iglesia. Algunas de estas inhumaciones alteran el suelo originario del pórtico septentrional, de las cuales una se podría asociar con la inscripción grabada sobre la jamba oriental de la puerta norte de la nave que, entre dobles líneas para separar los renglones, recoge el epitafio del abad Esteban (A110, UE1085), fallecido en 1132 (GÓMEZ-MORENO, 1925: 123; CORTÉS SANTOS, 2005: 192). Pero los epitafios más comunes presentan un desarrollo menor, como el situado sobre el muro oeste de la habitación norte (A110, UE1033).
Con estas mismas características existen otros epígrafes, como el situado en la parte inferior del muro oeste del ábside occidental (A110, 1033 1063), los cuales, según GÓMEZ-MORENO (1925: 122), no superan el siglo XI. Estos se pueden relacionar seguramente con las inhumaciones de lajas hincadas con orejetas documentadas en las citadas excavaciones. Otra cuestión es la inscripción presente sobre el dintel de la habitación lateral sur, sobre la que se grabaron una serie de cadalsos de carácter popular (A110, UE1020).

Con posterioridad al uso cementerial que acabamos de describir, y que en ningún caso parece sobrepasar el siglo XIII, el perímetro de la iglesia es reformado. El análisis estratigráfico de la cerca perimetral de la iglesia nos ha permitido individualizar en ella diferentes estructuras de mampostería de lajas de cuarcita que corresponderían a esta renovación de los espacios perimetrales (Fig 1). El pórtico septentrional es sustituido por una nueva estancia de menor anchura (A121, UE1067), cuyos cimientos, como indican los resultados de la excavación (CORTÉS SANTOS, 2005: 185), alteran los suelos originarios. La nueva estancia se alinea con la fachada occidental de la iglesia, adosada sobre su ángulo norte, donde sitúa una puerta (A121, UE1066 1067).

Frente a la fachada occidental de la iglesia y de la nueva estancia septentrional, separada por un pasillo o callejón de unos 2,00 m de anchura, se construye otra estancia que, aunque alterada por la edificación de la espadaña (A139, UE1094 1095), parece delimitar un espacio de mayor anchura que el de la iglesia (A139, UE1093 1096). El pasillo presenta una puerta en su extremo septentrional solidariamente construida con las dos estancias que la delimitan (A121, UE1067; A139, UE1096).

Frente a la fachada meridional, localizamos en la misma cerca perimetral otro tramo de muro de mampostería de lajas de cuarcita (A140, UE1092). Este aún conserva restos de un acabado de mortero de cal pintado de rojo, del mismo tipo que el preservado en la fachada occidental de la habitación sur. 
Y en un momento impreciso de esta fase, el mantenimiento de las cubiertas supuso la alteración de la posición originaria de al menos 11 modillones polilobulados del alero del tramo oriental de la nave (A124, UE1073: modillones número 3, 4, 9, 10, 11, 14, 15, 25, 42, 43 y 44), algunos situados en pequeños cajeados de $2 \mathrm{~cm}$ de altura abiertos sobre la línea de imposta. Durante esta fase se incluyen parejas de nuevas piezas escasamente desbastadas (A124, UE1078: modillones número 17 y 18; A124, UE1079: modillones número 19 y 22; A124, UE1083: modillones número 38 y 39; y A124, UE1084: modillones número 40 y 41) como soportes de las cubiertas.

\section{Fase 3. Adecuaciones modernas ${ }^{8}$}

A102, UE1004; A103, UE1007 1009 1010; A105, UE1006; A106, UE1003; A111, UE1029; A114, UE1044 1046; A115, UE1047; A116, UE1054; A118, UE1057 1058 1061; A119, UE1017 1021 1031103510371051 1055; A122, UE1069; A125, UE1072 1075 1077; A126, UE1081; A136, UE1089; A137, UE1090; A138, UE1038

La siguiente fase incluye transformaciones propias de la reforma litúrgica del periodo moderno. La introducción de un retablo en la cabecera supone el cierre (A105, UE1006; Fig. 3) de la ventana originaria y la apertura de otra nueva (A103, 10071009 1010), a mayor altura, en el muro septentrional. Probablemente, en relación con esta reforma, se lleva a cabo la reparación (106, UE1003; Fig. 20) de la cornisa del ábside oriental y de los modillones (A111, UE1029) del alero de la habitación norte.

Otra reforma corresponde a la instalación de un púlpito en el muro norte del tramo occidental de la nave, al cual se accede desde el exterior por medio de un amplio vano abierto en la pared (A138, UE1038). Quizá es en este momento, si no antes, cuando se ciega la puerta inmediata del muro norte. Las jambas de este vano conservan aun las huellas (A136,
UE1089) del muro de mampostería que sirvió de cierre.

Probablemente sea en este momento, con la nueva ornamentación de la iglesia, cuando se instalen también las rejas que sustituyeron a las celosías originarias de las ventanas, cuyos huecos de encastre se conservan en las jambas (A115, UE1047).

El resto de reformas documentadas corresponde a actividades de mantenimiento como las llevadas a cabo en las cubiertas del pórtico meridional, que eleva su altura (A118, UE1057 1058 1061). Los aleros del tramo occidental de la nave se reconstruyen (A114, UE1044 1046), manteniendo la altura originaria, incluyendo 14 nuevos canes de media nacela, tallados con gradina, y reutilizando en el extremo occidental sendos modillones polilobulados (modillones número 53 y 54). Los aleros del tramo oriental de la nave incluyen canes del mismo tipo en las esquinas y el centro de sus fachadas este y sur (A125, UE1072: modillones número 1 y 6; A125, UE1075: modillones número 12; A125, UE1077: modillón número 16), junto a los cuales se reutilizan dos modillones polilobulados (A125, UE1072: modillón número 2; A125, UE1075, modillón número 13). El can central de la fachada norte es sustituido por una laja desbastada sobre la que se grabó la fecha "1690" (A126, UE1081: modillón número 28).

Por sus características, consideramos que no mucho más tarde de este periodo se construyó una espadaña exenta (A122, UE1069) frente a la fachada occidental del edificio. Para acceder a ella, se elevó sobre el ábside occidental un cuerpo ciego de mampostería (Fig. 22) con cubierta a dos aguas (A116, UE1054) que permitió colgar una estructura de madera entre ambas construcciones, a la cual se llegaba por una escalera por la fachada septentrional. Ya GÓMEZ-MORENO (1919) y con más detalle LUENGO (1961: 35) deducen

8 Como en la fase medieval, las referencias a la fase moderna sobre la iglesia de Santiago son escasas. Los libros de fábrica, conservados en el archivo diocesano de Astorga, y un libro de cuentas, de la casa rectoral, recogen información al respecto que en la actualidad está transcribiendo y analizando el historiador José Miguel Lorenzo Arribas. 


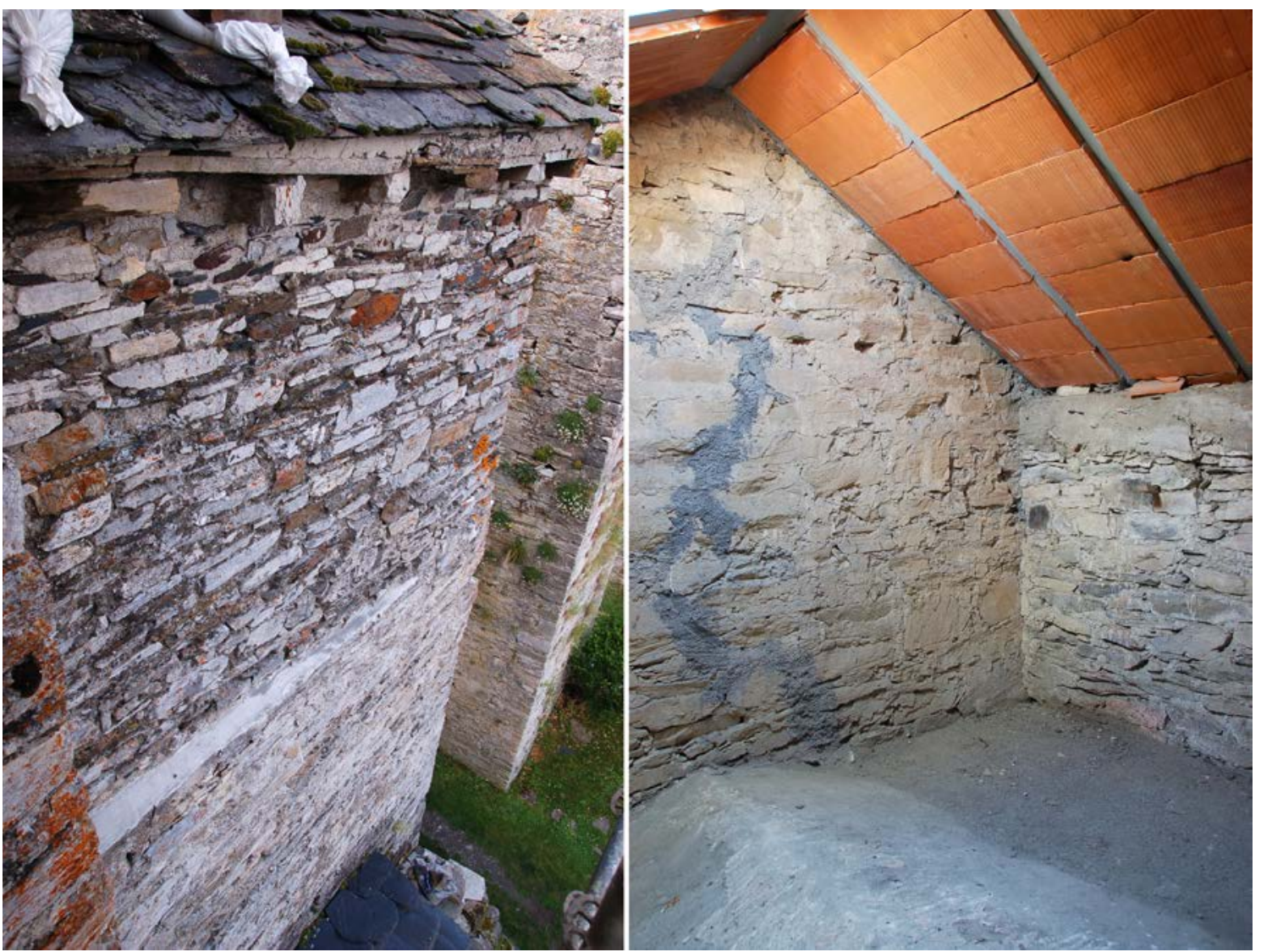

Fig. 22. Fachada septentrional y espacio interior adosado sobre el tramo occidental del aula de la cámara recrecida sobre el ábside occidental

que el cuerpo superior del ábside occidental corresponde a un nuevo añadido que se construyó una vez eliminada la cornisa originaria. MARTÍNEZ TEJERA (2010: 79) propone que esta actividad se pudo llevar a cabo en la etapa siguiente, entre los años 1879 y 1894. La posterior desaparición del cadalso añadido muestra huellas de las vigas que apoyaban sobre la espadaña y el cuerpo superior del ábside occidental. Frente a la actual imagen que nos ofrece el edificio, los ábsides oriental y occidental originarios se construyeron con una altura similar, cubiertos a tres aguas.

Las partes altas de los elementos precedentes a esta fase quedan en numerosas ocasiones ocultos, siendo hoy reconocibles bajo cargas de mortero con desgrasantes pizarroso generalizado a todo el edificio (A102; UE1004; A119, UE1017 10211031103510371051 1055). La espadaña también recibe este tipo de revoco (A137, UE1090). En definitiva, una importante actividad reformadora que podría rela- cionarse con el nuevo acabado integral que cubren las pinturas originarias al interior de la iglesia, donde también se emplea una base de mortero con desgrasantes pizarroso, y que los responsables de la restauración fechan entre finales del siglo XVI y a lo largo del XVII (Fig. 13).

\section{Fase 4. Reparaciones puntuales: Post barroco}

A104, UE1008; A107, UE 1011 1012; A112, UE 1032; A120, UE1064; A127, UE 1080 1082; A132, UE1039; A134, UE 1065

En contra de lo que desde GÓMEZ-MORENO (1919) se viene repitiendo, creemos que el cenotafio que la investigación adscribe al de San Frontis (A134, UE1065), adosado a la fachada septentrional del ábside occidental, fue construido en una fase moderna, ya que está situado sobre estructuras precedentes (A121, UE1066, Fase 2), previamente desmanteladas, que delimitaban una estancia en 
este lugar (Fig. 23). Emplea para su construcción piezas mal ajustadas, con elementos decorativos que siempre han sido considerados como propios del periodo románico. La excavación arqueológica muestra que el arranque de sus muros apoya directamente sobre el suelo que presentaba esta zona durante su etapa originaria. Quizá esta actividad pueda estar en relación con una serie de obras llevadas a cabo en la iglesia de Santiago entorno al año 1775 por el Cabildo de la Catedral de Astorga, quien "reedificó el Claustro y la portada, hizo puertas nuevas, reparó los sepulcros y separó con un muro el Cementerio de Sacerdotes y seglares" (BERJÓN y VÁZQUEZ, 1902: 112-113).

Incluimos en esta fase la renovación de los modillones del tramo oriental de la nave, que en el ángulo este
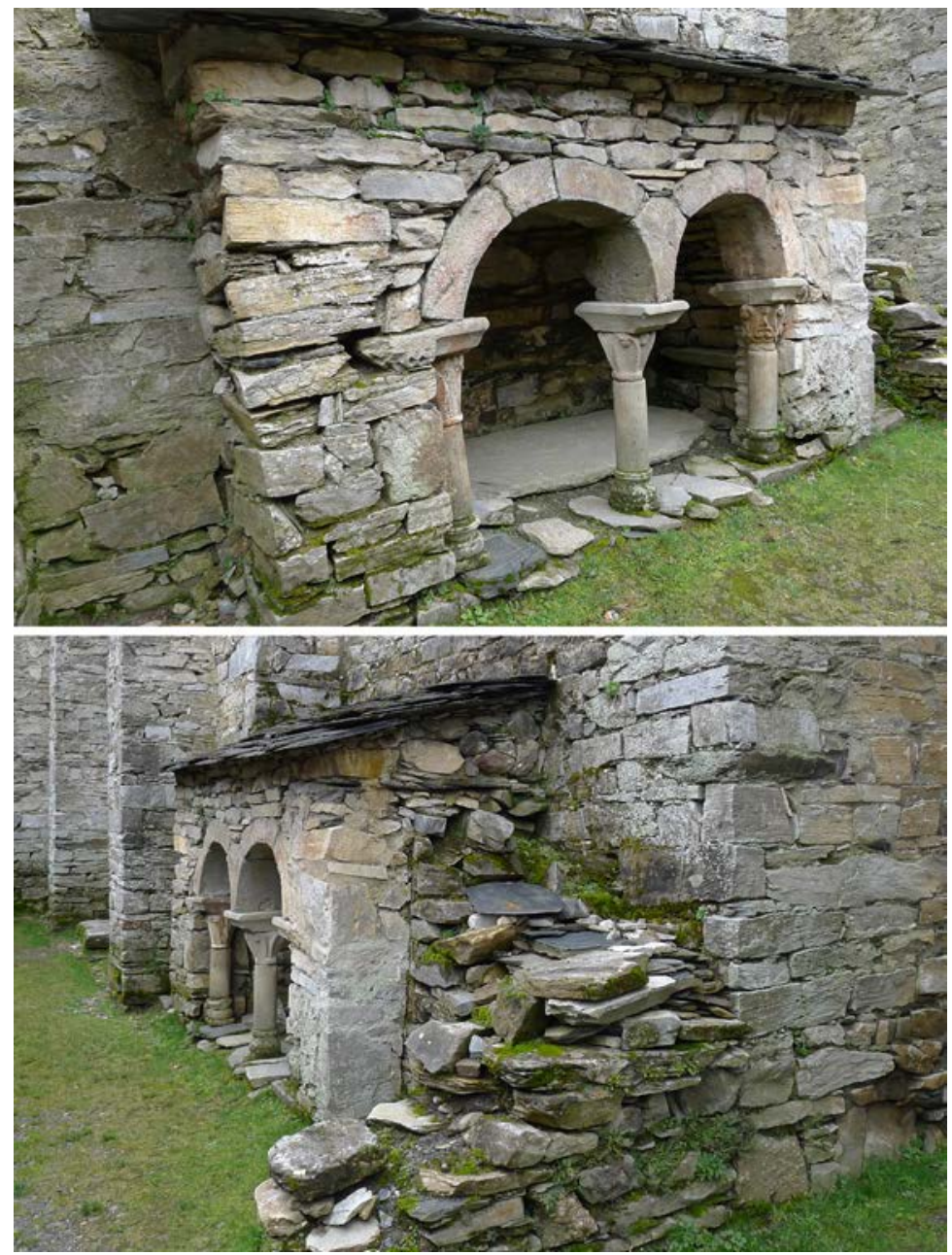

Fig. 23. Cenotafio adosado a la fachada norte del ábside occidental emplean canes de media nacela, tallados con gradina (A127, UE1080: modillones número 23 y 24), y en el oeste lajas desbastadas (A127, UE1082: modillones número 30, 31, 33 y 34). En concreto, el modillón 31 presenta labrada la fecha "1880". Estos últimos combinan dos modillones polilobulados (A127, UE1082: modillones número 32 y 35).

Y finalmente, gracias a la descripción que nos ofrece GÓMEZ-MORENO $(1909,1919)$, consideramos que no más tarde de esta fase se llevaron a cabo diferentes actividades, como el desmantelamiento del púlpito instalado en el muro norte de la nave, incluyendo el cierre (A132, UE1039) del vano por el que se accedía. Situamos no más tarde de este momento también la reparación del alero del ángulo suroeste del ábside oriental (A107, UE1011 1012), el cegado del vano abierto en el muro norte del

ábside oriental (A104, UE1008) y la deformación que se observa en el centro del muro norte de la habitación norte (A112, UE1032). No más tarde de esta fase será alterada la celosía (A120, UE1064) del ábside occidental, la única de la cual conservamos evidencias.

\section{Fase 5. Nuevas cubiertas, la cerca y la espadaña: Restauraciones del siglo XX}

A108, UE1015 1016; A128, UE1014 10221023 10251042104310451059106810701091 1097 1098; A130, UE1026 10271087 1088; A135, UE1086; A141, UE1099

La siguiente fase incluye las reformas programadas que se llevaron a cabo después de la declaración de Santiago de Peñalba como Monumento Histórico Artístico en el año 1931. 
Aunque aún son reconocibles reformas de carácter popular, como la reconstrucción de la imposta y alero de madera de la habitación sur (A108, UE1015 1016). Incluimos aquí la restauración del muro oriental de la habitación norte, en el cual se abre la aspillera que ilumina la habitación (A130, UE1026 1087), cegando así la originaria (A130, UE1088). Esta reforma incluye una inscripción funeraria antigua (A110, UE1027) que se refiere a un tal Petronatus. También ahora se incorpora una reja en la ventana del ábside oriental (A135, UE1086).

El arquitecto Menéndez Pidal en el año 1949 propuso recolocar piezas desprendidas del alero reintegrando canes desaparecidos. Ordenó además eliminar las acumulaciones deposicionales sobre la cabecera y derribar edificaciones anejas, como el pórtico de la fachada meridional (A128, 1059). Aprovechando restos de elementos precedentes construye una cerca perimetral que al este actúa como muro pantalla (A128, UE 1068) y al sur incluye una puerta (A128, UE 1097). La cerca perimetral incluye el cegado de la puerta septentrional que daba acceso al pasillo o callejón existente frente al testero occidental de la iglesia (A128, UE 1098) (Fig. 1). En el año 1956 eliminó el revestimiento que cubría el edificio y en 1964 comienza a construir una nueva cubierta de grandes lajas de esquito sin desbastar, la cual asentó sobre unos faldones de hormigón armado directamente apoyados en la nave sobre el trasdós de piedra de las bóvedas. Hacia el 1971 desmantela el cadalso que daba acceso a la espadaña y lo sustituye por unas escaleras adosadas (A128, UE 1070) ${ }^{9}$. En los ábsides la nueva cubierta fue concluida el año 1975 por el arquitecto González Mercadé, quien empleó hormigón armado sobre bovedilla recreciendo la pendiente de la cubierta del ábside occidental con una estructura metálica (A128, UE 1091).

Estas actuaciones deben coincidir con la reconstrucción de las partes altas (A128,
UE1014 1022102310421043 1045) de todos los contrafuertes. El de la fachada oriental de la habitación norte es reconstruido por completo (A128, UE 1025).

Al oeste del recinto perimetral, arrancando desde sus estructuras precedentes, se levantan sendos muros (A141, UE1099) que parecen relacionarse constructivamente con las edificaciones al oeste de ellos.

\section{Fase 6. Últimas actuaciones de man- tenimiento: Contemporáneo}

A129, UE1005 1062; A131, UE1030; A133, UE1052

Para concluir, atribuimos a esta fase aquellas actividades del siglo XXI que han afectado al edificio, como la reconstrucción de la cubierta de la habitación norte de lajas de pizarra obtenidas con medios mecánicos, las mismas que se emplean en el tejadillo del contrafuerte noroeste del aula (A130, UE1030). También se introducen piezas de alabastro (A133, UE1052) para hacer un cierre permeable en las ventanas de la nave. Y reconocemos numerosos repasos de cemento de carácter parcial (A129, UE1062) en zonas de la nave y del cenotafio situado al norte, así como otros sistemáticos, como el que rejunta (A129, UE1005) el cuerpo inferior del ábside oriental.

No queremos dejar de incluir en esta fase las huellas que han provocado en el edificio recientes actuaciones, como la restauración de la amplia secuencia pictórica que ocultaba el acabado originario de sus fábricas, limpiándolo y consolidándolo, una vez fueron eliminadas costras salinas, carbonataciones y revocos modernos. En este sentido, la excavación arqueológica afectó principalmente a los suelos originarios del edificio, en los cuales se abrieron una serie de cortes controlados.

\footnotetext{
9 Proyectos depositados en el Archivo General de la Administración (Alcalá de Henares, Madrid) firmados por los arquitectos L. Menéndez-Pidal y Álvarez y F. Pons Sorolla: "Proyecto de restauración de Santiago de Peñalba. Alero exterior pétreo y cubierta de pizarra”, C-71.081, abril de 1949; "Obras generales", C-71.171, mayo de 1964; "Consolidación exterior", C-70.835, enero de 1967; y "Restauración del campanario-espadaña y paramentos.", C-71.125, abril de 1971.
} 


\section{CONCLUSIÓN}

El análisis estratigráfico del edificio permite confirmar que fue diseñado y construido de forma unitaria, levantando todos sus tramos al mismo tiempo, de forma solidaria (Fig. 24). Esta propuesta se alinea con la ya defendida por GÓMEZ-MORENO (1919: 227-230), la cual certificó el posterior resultado de la excavación arqueológica de la iglesia (CORTÉS SANTOS, 2011: 171-174). Sin embargo, los resultados refutan teorías alternativas que subordinaron las evidencias materiales del edificio al análisis estilístico y de las fuentes, como la enunciada por FONTAINE (1978; seguido por REGUERAS, 1990), quien supone la puerta sur incluida con posterioridad; la defendida por

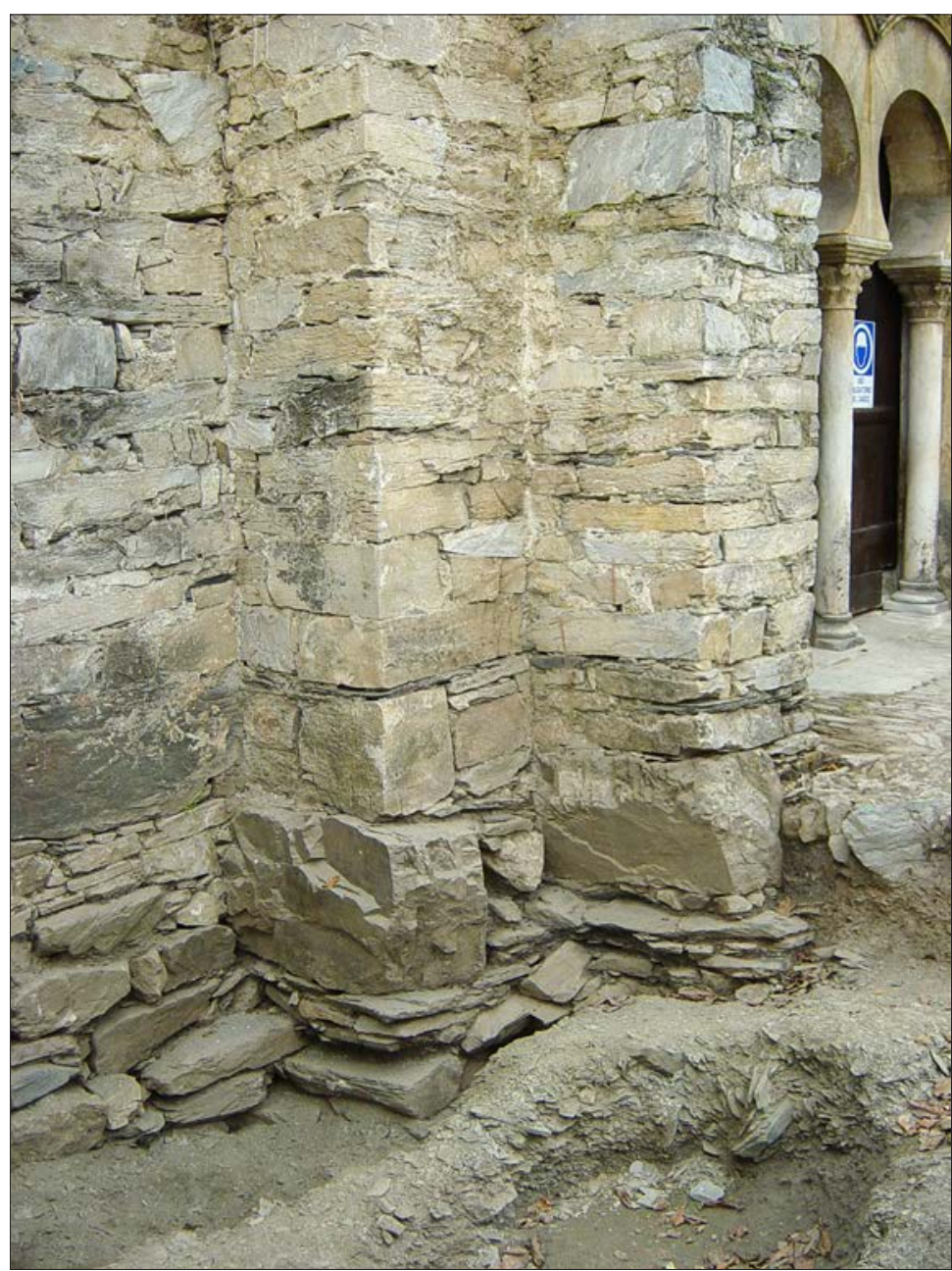

Fig. 24. Cimientos de la fachada meridional del ábside occidental constructivamente unitarios con el ángulo suroccidental del aula
PASTRANA (1987), acerca de la posterioridad de las habitaciones laterales; o la propuesta por BANGO (1992: 100; seguido por MARTÍNEZ TEJERA, 1993; y negada por ARBEITER, NOACKHALEY, 1999: 299), sobre la posterioridad constructiva del ábside occidental. El análisis arqueológico del edificio muestra, por un lado, que cuando se comenzaron a construir los cuerpos superiores de la nave, los ábsides y las habitaciones laterales ya estaban terminadas, y por otro, que los elementos singulares o decorativos (basas, fustes, capiteles, cimacios y celosías) son unitarios a los muros. El diseño y puesta en obra de estas piezas permite afirmar que fueron realizadas para decorar el edificio, a excepción de los fustes del interior de la nave, en los que se observa signos de reutilización (cortes, combinación de piezas, y presencia de éntasis). En cualquier caso, estas observaciones no impiden concluir que el taller decorativo estuvo presente en la obra ${ }^{10}$. Tomando en cuenta el proceso constructivo de la iglesia, de forma solidaria, y el estado inacabado de un grupo de modillones polilobulados, suponemos que el taller decorativo está bien coordinado con los promotores y diseñadores del edificio. Debía existir una demanda programada con suficiente antelación. El estado inacabado de algunas piezas nos hace sospechar que el taller no es capaz de cumplir con los plazos del constructor y por ello este decide usar el material en el estado que lo encuentra, inacabado, característica por otro lado común en el grupo Mozárabe, como se puede comprobar en Escalada y Mazote (TORRES BALBAS, 1936: 257). La reutilización de

10 Ver discusión en VILLA, en este mismo monográfico. 
material constructivo también afecta a los dinteles de madera de los accesos a las capillas laterales síntoma que viene anunciado por las huellas de usos precedentes y confirmado por la fecha de tala del árbol del que se extrae la pieza, situada a mediados del siglo VIII (Ver al final del texto Resultados del análisis dendrocronológico). Este aspecto nos remite a casos como el conocido de la iglesia zamorana de San Pedro de la Nave (MATHIAS et alii, 1998) donde la reutilización de material constructivo de madera es también una posibilidad.

Las características del diseño, la ejecución y el acabado del edificio son propias del periodo al que tradicionalmente se ha atribuido su construcción (GÓMEZ-MORENO, 1919), aspectos que, junto al uso de elementos decorativos como el alfiz, o las características técnicas y formales de sus capiteles (NOACKHALEY, 1990; ARIAS PÁRAMO, 1996), pueden ser considerados de marcado carácter califal. En este sentido, ARBEITER y NOACK-HALEY (1999: 297) no dudan en comparar el arco geminado de la portada meridional con el empleado en el alminar que conserva la iglesia cordobesa de San Juan. Lo mismo ocurre para las pinturas murales que acaban el interior de la iglesia (TEJEDOR, SUÁREZ-INCLÁN, 2006), las cuales cuentan con una definición cronológica precisa gracias a la documentación de la inscripción del año 937 (GUARDIA PONS, 2007: 118-119), o con los modillones polilobulados que pueblan los aleros del edificio (GÓMEZMORENO, 1919). Aunque algunas de las características de estos últimos no se aprecian en al-Ándalus como son la mayor dimensión que proyectan y la profusa decoración de sus costados (TORRES BALBAS, 1936: 254-255).

El único replanteamiento que el análisis detecta durante el proceso de construcción de la iglesia es el que afecta a la ventana del ábside occidental la cual fue dotada con una luz menor a la previamente diseñada.

Los resultados de la excavación, análisis que tuvo en cuenta las características materiales del edificio, nos permite certificar el adosamiento de sendos pórticos laterales, construidos a continuación del primer uso que tuvo la iglesia (CORTÉS SANTOS, 2005: 183-186). El situado al norte supone la reforma de una estancia originaria que sellaba con su pavimento un cementerio coetáneo, actividad funeraria que continuó en este espacio después de su reforma. Consideramos que la existencia de algunos elementos singulares, almacenados en el edificio o reutilizados con funciones para las que no estaban diseñados, de características comunes al periodo originario, como el salmer de un arco geminado de herradura o la imposta exenta de mármol que remata la cubierta del tramo oriental del aula (Fig. 25), podrían haber formado parte de estos espacios añadidos. Pudieron formar

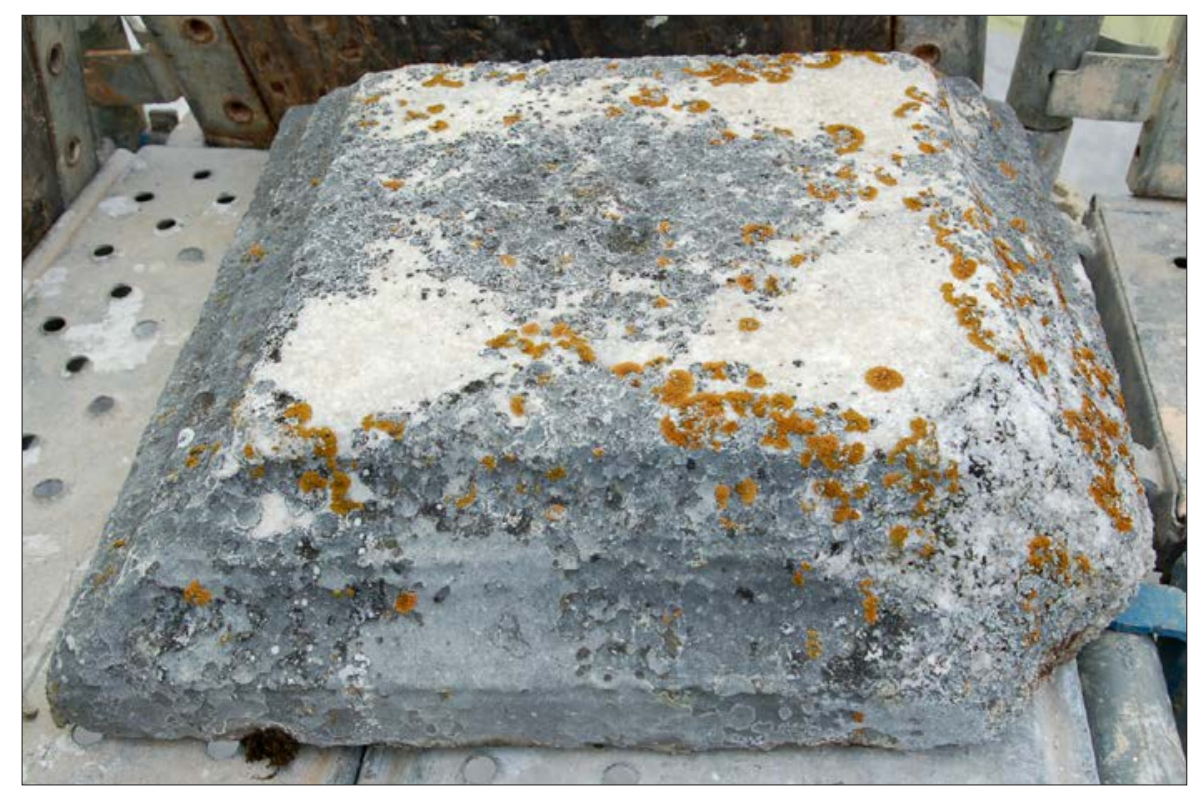

Fig. 25. Imposta reutilizada en el remate de la cubierta del tramo oriental aula 
parte de otro acceso geminado, o quizá, de una arquería mayor como la que, incorporada también en un segundo momento, protege la fachada meridional de Escalada. Aunque no se debe desestimar que también podrían formar parte de alguna estancia del posible monasterio sobre las cuales ya algún autor ha incidido (LUENGO MARTíNEZ, 1961), espacios que se distribuirían alrededor de la iglesia sin una planta aun normalizada por la reforma benedictina.

En cuanto a su acabado, el edificio debió presentar al exterior un aspecto uniforme y brillante, en el que no destacaba la fábrica de mampostería. El mortero cubriría las paredes, sin suponer una carga masiva para ellas, dejando el centro del mampuesto libre, en mayor o menor medida (Fig. 26). El análisis nos ha permitido comprobar que fue durante la construcción, cuando se acabaron los muros, con remates durante el proceso de desmonte del andamiaje, y no una vez construidos.

Desde el apartado estructural, coincidimos con diagnósticos previos que no observan en las fábricas de la iglesia desplomes o pandeos, aunque son reconocibles grietas en arcos y bóvedas de la nave (CORTÉS SANTOS, 2011: 162, 172). Otra cuestión son las humedades que aparecen periódicamente en los alzados interiores del edificio. La arquitecta GARCÍA MORALES (1993), tras un análisis específico del edificio, evidenció que los problemas no eran de capilaridad, sino de impermeabilidad de los muros, los cuales dejaban pasar agua a través de huecos y fisuras y se condensa-

Fig. 26. Vistas del exterior de la iglesia desde sur-este donde se puede observar la mampostería de sus muros parcialmente cubierta por el acabado original y sus sucesivas reparaciones (GÓMEZMORENO, 1925: Fig. 46) ba en su interior, circunstancia agravada por una escasa ventilación. Los resultados del análisis estratigráfico son coincidentes con esta opinión, al certificar que el revoco originario de la iglesia y los revestimientos aplicados para su mantenimiento se han perdido, dejando los muros de la iglesia desprotegidos. Sin embargo, conseguir en la actualidad de nuevo un acabado satisfactorio se nos antoja difícil, ya que el originario se obtuvo durante la construcción de los muros, no ya una vez construidos, con morteros superpuestos.

\section{BIBLIOGRAFÍA}

ÁLVAREZ VILLAR, Julián (1954): El Bierzo en la Historia. León, s/e.

ARBEITER, Achim; NOACK-HALEY, Sabine (1999): Christliche Denkmäler des frühen Mittelalters vom 8. Bis ins 11. Jahrhundert. Mainz am Rhein, Philipp von Zaben.

ARIAS PÁRAMO, Lorenzo (1996): San Salvador de Valdediós. Gijón, Ediciones Trea.

BANGO TORVISO, Isidro (1992): "El espacio para enterramientos privilegiados en a la arquitectura medieval española", Anuario del departamento de Historia y Teoría del Arte. IV. Madrid, Universidad Autónoma de Madrid, 93-132.

BERJÓN Y VÁZQUEZ, Antonio (1902): Nuevo lucífero para la historia de la diócesis de Astorga. Astorga, Tipografía de N. Fifalgo.

CABALLERO ZOREDA, LUis; LATORRE GONZÁLEZ-MORO, Pablo (coord. 1995): Leer el documento construido. Informes de la Construcción (monográfico). 46, 435. Madrid, Instituto Eduardo Torroja.

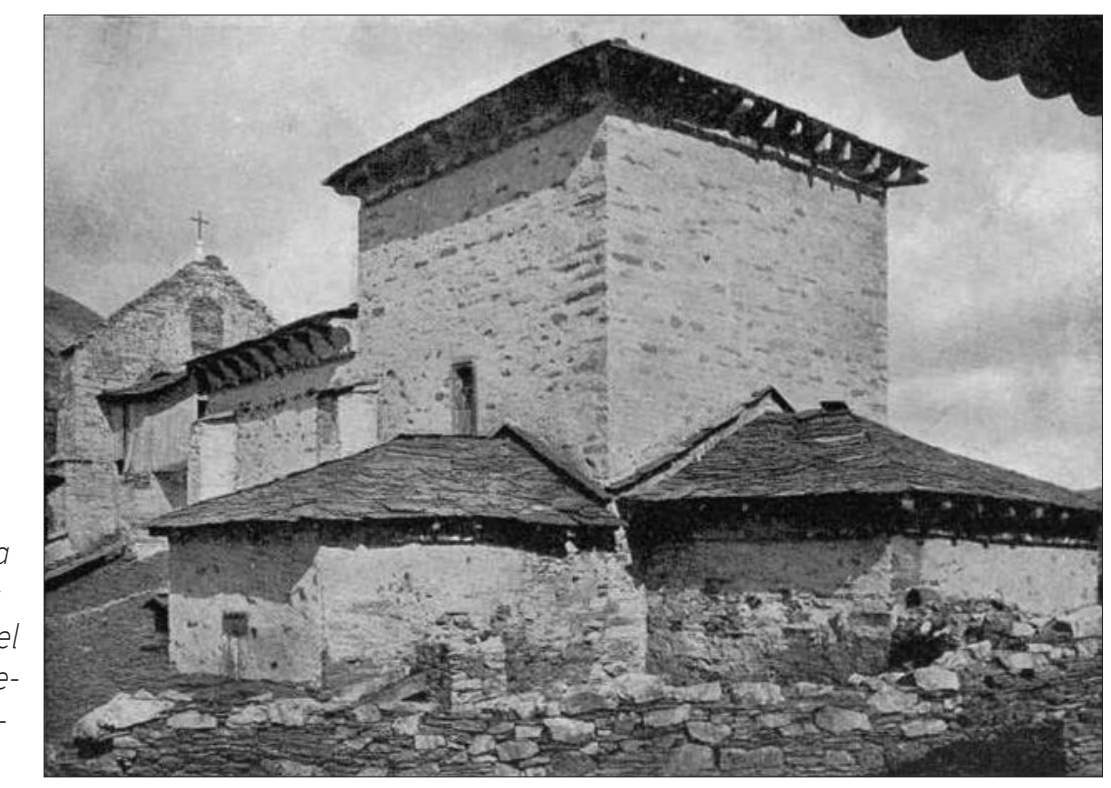


CABALLERO ZOREDA, Luis; ESCRIBANO VELASCO, Consuelo (coord. 1996): Curso de Arqueología de la Arquitectura. El método arqueológico aplicado al proceso de estudio y de intervención en edificios históricos. Burgos, Junta de Castilla y León.

CORTÉS SANTOS, José Luis (2005): "Adelanto de las conclusiones sobre la intervención arqueológica en la iglesia de Santiago, Peñalba de Santiago (León)", Tierras de León. 43. León, Diputación de León, 120-121 y 159-205.

DURANY CASTRILLO, Mercedes; RODRÍGUEZ GONZÁLEZ, María del Carmen (1998): "Ocupación y organización del espacio en el Bierzo Bajo entre los siglos V al X”, El poblamiento altomedieval galaico-astur-leonés: herencia prerromana, romana y visigoda, Studia historica. Historia medieval. 16. Salamanca, Ediciones Universidad de Salamanca, 45-87.

FONTAINE, Jean (1978): El mozárabe. Madrid, Ediciones Encuentro.

GARCÍA MORALES, Soledad (1993): Iglesia de Santiago de Peñalba: estudio de las humedades. Memoria inédita depositada en la Junta de Castilla y León, Valladolid.

GÓMEZ-MORENO, Manuel (1909): "Santiago de Peñalba. Iglesia Mozárabe del siglo X”, Boletín de la Sociedad Castellana de Excursiones. IV, 81. Valladolid, Sociedad Castellana de Excursiones, 192-204.

GÓMEZ-MORENO, Manuel (1919): Iglesias mozárabes. Arte español de los siglos IX al XI. Granada, Editorial Universidad de Granada.

GÓMEZ-MORENO, Manuel (1925): Catalogo Monumental de España Provincia de León (1906-1908). Madrid, Ministerio de Instrucción Pública y Bellas Artes.

GUARDIA PONS, Milagros (2007): "De Peñalba de Santiago a San Baudelio de Berlanga. La pintura mural de los siglos X y XI en el reino de León y Castilla. ¿Un espejo del al-Ándalus?", Simposio Internacional "El legado de Al-Ándalus. El arte andalusí en los reinos de León y Castilla durante la Edad Media". Valladolid, Fundación de Patrimonio Histórico de Castilla y León, 115-156.

ITO, Yoshihico (2012): "Las bóvedas de ladrillo fingido en la iglesia de Santiago de Peñalba y los préstamos estéticos de monumentos antiguos en el reino de León en el siglo X", Anuario del departamento de Historia y Teoría del Arte. 24. Madrid, Universidad Autónoma de Madrid, 9-26.

LUENGO MARTÍNEZ, José María (1961): "De la Tebaida leonesa: Montes y Peñalba”, Tierras de León. 1, 2. León, Diputación de León, 25-42.

MARTÍNEZ TEJERA, Artemio Manuel (1993): "El contraábside en la arquitectura de Repoblación: el grupo castellano-leonés", Actas del III Curso de Cultura Medieval. Aguilar de Campoo, Centro de Estudios del Románico. 149-161.

MARTÍNEZ TEJERA, Artemio Manuel (2010): La "ecclesia" de Peñalba de Santiago (El Bierzo, León): Arquitectura de fusión del siglo X en el antiguo reino de León. Rivas Vaciamadrid, Asociación para el Estudio y Difusión del Arte Tardoantiguo y Medieval.
MATHIAS, Fernán Alonso; CABALLERO ZOREDA, Luis; RODRÍGUEZ TROBAJO, Eduardo (1998): "Datación de una viga de la iglesia de S. Pedro de la Nave", Archivo Español de Arqueología. 71. Madrid, Instituto Español de Arqueología, Consejo Superior de Investigaciones Científicas, $177-178$ y 283-294.

MORALES, Ambrosio de (1791): Crónica general de España. Tomo VI. Madrid, Oficina de Benito Cano.

NOACK-HALEY, Sabine (1990): "Capiteles Mozárabes", EWERT, Chirstian; CRESSIER, Patrice; ZOZAYA, Juan (Ed): Coloquio Internacional de capiteles corintios, prerrománicos e islámicos (sS VI-XII d.c.). Madrid, Ministerio de Cultura, 37-52.

PALOMINO LÁZARO, Ángel Luis (2013): Estudio estratigráfico de la intervención en la cubierta de la iglesia de Santiago de Peñalba. Memoria inédita depositada en la Junta de Castilla y León, Valladolid.

PASTRANA GIMÉNEZ, Luis (1987): Peñalba, Montes y Compludo. León, Ediciones Lancia.

QUADRADO, José María (1885; Reed. 1987): Asturias y León. España, sus monumentos y sus artes, su naturaleza e historia. Madrid, Ediciones Lancia.

QUINTANA PRIETO, Augusto (1956): "Las fundaciones de San Genadio", Archivos leoneses. 19. León, Archivo Histórico Diocesano de León, 55-108.

REDONDO E IBÁÑNEZ, Inocencio (1904): Iglesias primitivas de Asturias. Oviedo, Comisión de Monumentos Históricos y Artísticos de la Provincia de Oviedo.

REGUERAS GRANDES, Fernando (1990): La arquitectura Mozárabe en León y Castilla. Salamanca, Junta de Castilla y León.

RODRÍGUEZ GONZÁLEZ, María del Carmen (1997): "Galicia desde o Bierzo. Proxección e diferencias na ocupación e organización do territorio", PEREIRA MENAUT, Gerardo (Coord.): Galicia fai dovs mil anos o feito diferencial galego. Vol. 1. Santiago de Compostela, Edición e deseño, 413-434.

TEJEDOR BARRIOS, Carlos; SUÁREZ-INCLÁN, María (2006): "Restauración de los paramentos murales de la iglesia de Santiago de Peñalba", Arqueología, arte y restauración: actas del IV Congreso Internacional "Restaurar la Memoria" (Valladolid 2004). Valladolid, Junta de Castilla y León, 105-136.

TORRES BALBÁS, Leopoldo (1936): "Los modillones de lóbulos. Ensayo de análisis de la evolución de una forma arquitectónica a través de diez y seis siglos", Archivo Español de Arte y Arqueología. XII. Madrid, Consejo Superior de Investigaciones Científicas, 159-290.

UTRERO AGUDO, María de los Ángeles (2006): Iglesias tardoantiquas y altomedievales en la Península Ibérica. Análisis arqueológico y sistema de abovedamiento. "Anejos de Archivo Español de Arqueología XL". Madrid, Consejo Superior de Investigaciones Científicas.

YEPES, Fray Antonio de (1609-1621; reedit. 1959): Crónica de la Orden de San Benito. Madrid, Biblioteca de autores españoles. 


\title{
Anexo 1. Resultado del análisis dendrocronológico
}

\author{
Eduardo Rodríguez Trobajo*
}

El acceso a las capillas laterales (norte y sur) de la iglesia de Santiago en Peñalba de Santiago presentan un arco de herradura en el paramento del aula más un umbral adintelado en la hoja interior del muro, de modo que el arco actúa de mocheta del cierre de sus puertas. Ambos dinteles son de tejo (Taxus baccata L.) con sección cuadrada igual (canto x tabla: $29 \times 28,5-29,5 \mathrm{~cm}$ ) y distintas longitudes (norte: 213; sur: $178 \mathrm{~cm}$ ). Las dos piezas son enterizas, es decir, labradas de troncos íntegros dejando la médula centrada, algo desviada en el cargadero norte. Resultado de la labra, las piezas se componen solo de duramen salvo una porción menor de albura en el extremo oeste del dintel sur, en una zona de fibra sinuosa. Se observan huellas de corte con hacha y restos de quemado superficial de las piezas.
El montaje de los dinteles es igual en las dos entradas con entregas de $1 / 3$ de la luz, excepto la este del dintel norte que tiene $1 / 2$ de la luz. En ambos casos existe un espacio de $4 \mathrm{~cm}$ entre la pieza y el trasdós del arco, que ha facilitado el aireado de las piezas. Ambos dinteles tienen gorroneras que en el norte aparecen duplicadas o corregidas, y en el sur se complementan con un segundo par tallado en la tabla del dintel a una distancia superior a la luz del paso. Podemos interpretar que estas labores fueron correcciones realizadas en el montaje de los dinteles, pero creemos más plausible que ambas piezas fueron reutilizadas (Fig. 1 anexo).

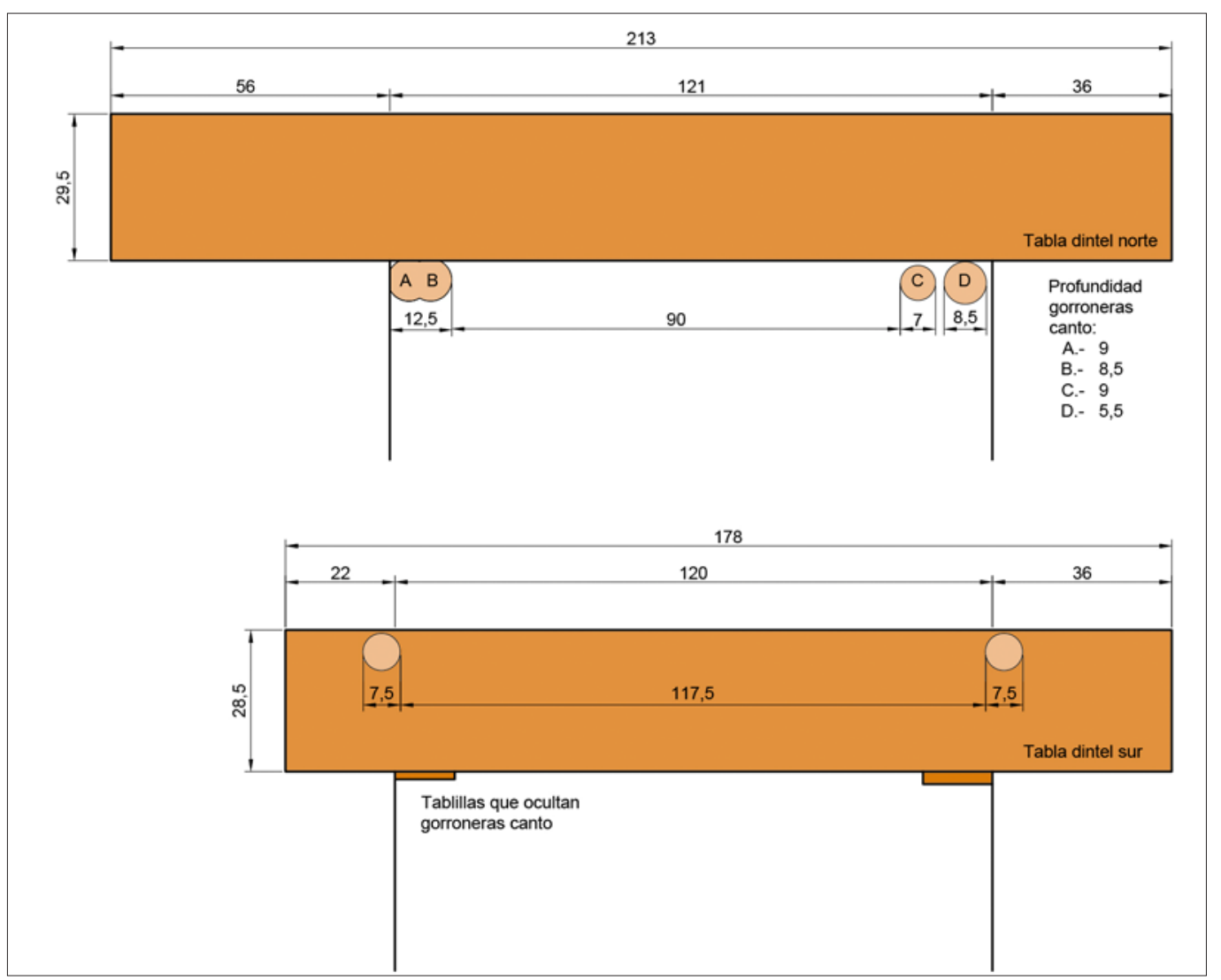

Fig. 1(anexo). Dimensiones de los descargaderos de madera de la puerta de acceso a la habitación norte y sur detallando la posición de las gorroneras

\footnotetext{
* Responsable del Laboratorio de Dendrocronología del Departamento de Productos Forestales del Centro de Investigación Forestal del Instituto Nacional de Investigación y Tecnología Agraria y Alimentaria
} 
La tipología de estos accesos es análoga a las habilitadas en otros edificios de los siglos X y XI. Al respecto, podemos referenciar la puerta suroeste del aula de la iglesia de San Miguel de Gormaz (CABALLERO ZOREDA, RODRÍGUEZ TROBAJO y MATHIAS, 1998: 33 y 37), con dinteles de sabina albar (Juniperus thurifera L.) y pino negral (Pinus pinaster Ait.), o la puerta suroeste de la iglesia de San Andrés de Fuentearmegil, con dintel de quejigo (Quercus faginea Lamk.). Las tres especies utilizadas en estos edificios sorianos son maderas propias de la cuenca del Duero.

El uso del tejo (Taxus baccata L.), para este periodo, se constata en las soleras insertas en el muro oeste de la nave central de la iglesia asturiana de Santo Adriano de Tuñón, y en el dintel del acceso a su habitación sur, donde se conservan unos restos (RODRÍGUEZ TROBAJO, 2010a: 159). Al igual que en Peñalba de Santiago, en esta iglesia se utilizó madera de tejo en un entorno en el que se supone habría una mayor disponibilidad de madera roble. Estos usos del tejo concuerdan con los dados en otros países, aunque es una madera más escasa y que dada su gran elasticidad, tradicionalmente, se ha utilizado en la elaboración de arcos, ejes y utensilios similares. También es conocido el uso de vigas de tejo en construcciones tradicionales de la región noroeste como cabrios de cubiertas por ser casi imputrescible frente a la humedad (ABELLA, 2009: 74).

El muestreo para dendrocronología se ha realizado en diferentes puntos de ambas piezas tratando de obtener secuencias lo más completas posibles y que incluyan restos de la albura. Se obtienen dos series: la serie 1 , correspondiente al dintel sur, con 143 anillos y 15 anillos de albura; serie 2, correspondiente al dintel norte, 148 anillos. Los anillos de la serie 1 presenta una media de 1,15 mm, y los de la serie 2 de $1,72 \mathrm{~mm}$, que son crecimientos similares a los medidos en las piezas de la iglesia de Santo Adriano de Tuñón y también la albura concuerda con la de ejemplares de la zona de edad similar que tienen 10-20 años. Por otra parte, estos valores son próximos a los encontrados en regiones europeas de mayor latitud (MOIR, 2004: 12).

La sincronización de las series $1 \mathrm{~A}$ y $2 \mathrm{~A}$ ha sido positiva:

\begin{tabular}{|c|c|c|c|c|}
\hline $2 \mathrm{~A} / 1 \mathrm{~A}$ & $\begin{array}{c}\text { Pos. relativa: } \\
116 / 139\end{array}$ & $\begin{array}{c}\text { Solapamiento: } \\
116\end{array}$ & $\mathrm{t}=4,52$ & $\mathrm{~W}=70$ \\
$(99,9 \%)$
\end{tabular}

Los valores indican que las piezas proceden de árboles distintos, si bien tenían edad y grosor parecidos y fueron cortados al mismo tiempo. Por el contrario, la serie media, con 153 años y anillo medio de $1,5 \mathrm{~mm}$, no ha podido ser interdatada con otras series de similar cronología, de tejo en Asturias y de roble en la cuenca del Duero (RODRÍGUEZ TROBAJO, 2010b: 181).

La datación carbono-14 de las piezas se ha realizado sobre el dintel norte (Serie 2) mediante una secuencia de 3 muestras distanciadas entre sí 50 años solares, procesadas por AMS (Universidad de Upsala, Suecia) que ofrece las siguientes edades-carbono:

\begin{tabular}{|l|l|l|}
\hline $2 \mathrm{~A}-1: 1435 \pm 40$ & $2 \mathrm{~A}-2: 1145 \pm 40$ & $2 \mathrm{~A}-3: 1270 \pm 35$ \\
\hline
\end{tabular}

La calibración de estos resultados con el programa OxCal detecta una notable anomalía de la muestra 2A-2 (Concordancia: 2,6\%), aunque hay que precisar que la heterogeneidad es relativa indicando una anomalía de esta muestra en relación a las otras dos, no pudiéndose descartar que las mediciones $2 \mathrm{~A}-1$ y $2 \mathrm{~A}-3$ sean las realmente anómalas.

Si consideramos la mayor improbabilidad de esta última opción, así como que es más verosímil una anomalía por contaminación de la muestra 2A-2, podemos ensayar una calibración de solo las medidas 2A-1 y 2A-3. Aplicando el programa GaussWM (Fig. 2 anexo) y añadiendo los 20 años estimados hasta la tala de los árboles, la datación de ambos dinteles sería:

\begin{tabular}{|c|c|c|}
\hline Estim. puntual: & Estim. de intervalo: & (GaussWM) \\
$933 \pm 11(68 \%)$ & $712-768(99 \%)$ & \\
\hline
\end{tabular}

Debemos tener en cuenta que este resultado es solo una hipótesis de datación ante la falta de nuevas mediciones que pudieran verificar su exactitud. Su aceptación nos lleva a la conclusión de que los dinteles fueron piezas labradas y utilizadas con anterioridad a la construcción de la supuesta fase originaria de la iglesia. En apoyo de esta hipótesis, las labores del cajeado para las gorroneras que se observan en ambos dinteles, así como la falta de un ajuste fino del grosor de los mismos al hueco del muro $(-4 \mathrm{~cm})$, serían también indicadores de que realmente se produjo una reutilización de la madera. 


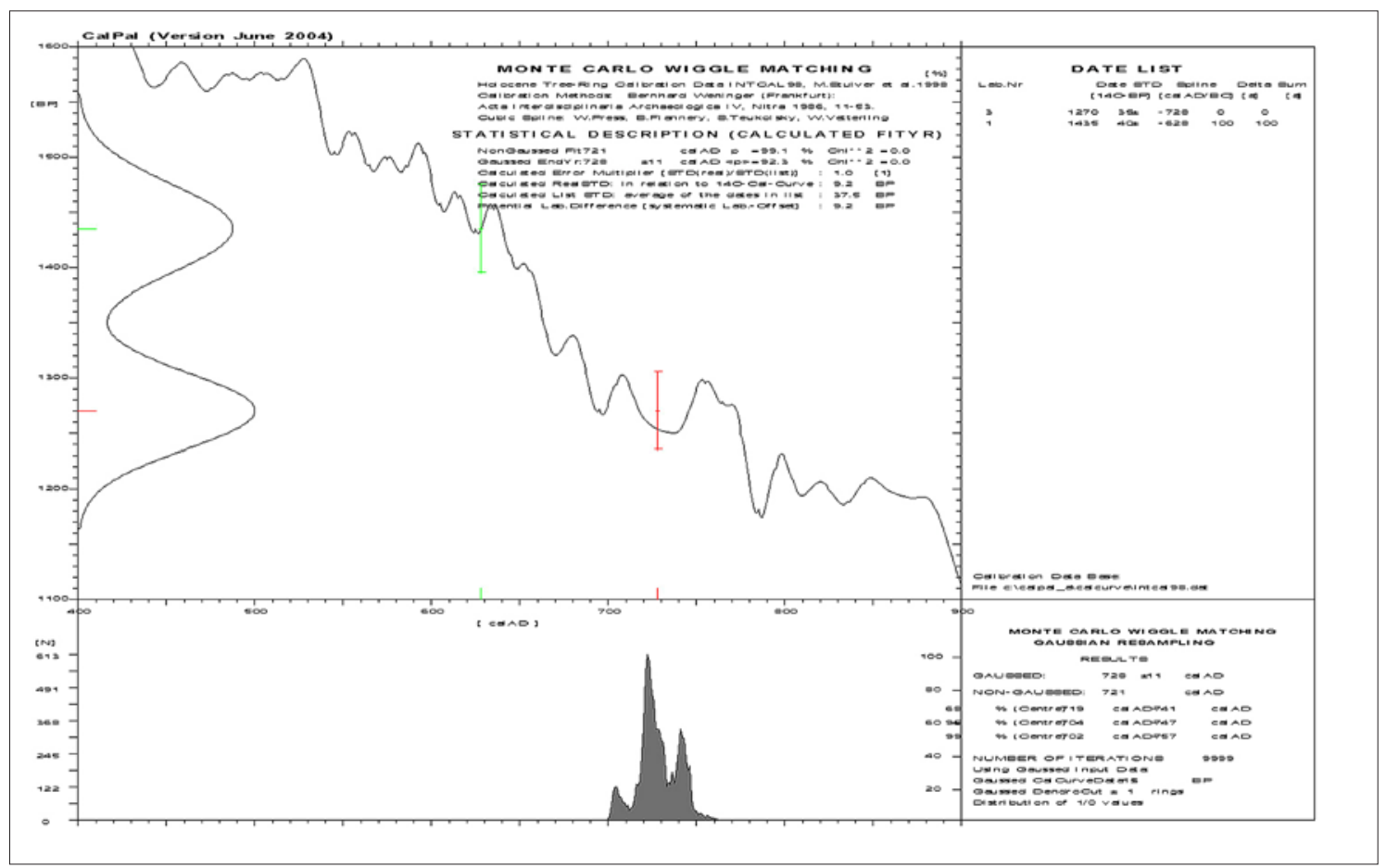

Fig. 2 (anexo). Calibración con el programa GaussWM

\section{BIBLIOGRAFÍA}

ABELLA, Ignacio (2009): La cultura del tejo. Esplendor y decadencia de un patrimonio vital. Valladolid, La editorial de Urueña.

CABALLERO ZOREDA, Luis; RODRÍGUEZ TROBAJO, Eduardo; MATHIAS, Fernán Alonso (1998): Análisis por dendrocronología y C14 de las maderas de las iglesias altomedievales de S. Pedro de la Nave, S. Miguel de Gormazy S. Baudelio de Berlanga. Memoria inédita depositada en la Junta de Castilla y León, Valladolid.

MOIR, Andy K. (2004): Dendrochronological analysis of a yew tree from St Marys churchyard, West Horsley, Surrey, England. Tree-ring Services Report: WHCX/33/04. Orpington, Kent, Tree-ring Services.
RODRÍGUEZ TROBAJO, Eduardo (2010a): Datación de Madera estructural en la Iglesia de Santo Adriano de Tuñón (Asturias), CABALLERO ZOREDA, Luis.; RODRÍGUEZ TROBAJO, Eduardo.; MURILLO FRAGERO, José Ignacio; MARTÍN TALAVERANO, Rafael: Las iglesias asturianas de Pravia y Tuñón. Arqueología de la Arquitectura. Anejos de Archivo Español de Arqueología. LIV. Madrid, Consejo Superior de Investigaciones Científicas, 154-177.

RODRÍGUEZ TROBAJO, Eduardo (2010b): Datación de dos puntales de madera en la iglesia de San Miguel de Lillo (Asturias), CABALLERO ZOREDA, Luis.; RODRÍGUEZ TROBAJO, Eduardo.; MURILLO FRAGERO, José Ignacio; MARTÍN TALAVERANO, Rafael: Las iglesias asturianas de Pravia y Tuñón. Arqueología de la Arquitectura. Anejos de Archivo Español de Arqueología. LIV. Madrid, Consejo Superior de Investigaciones Científicas, 179-184. 
Anexo 2. Diagrama y listado de Unidades Estratigráficas

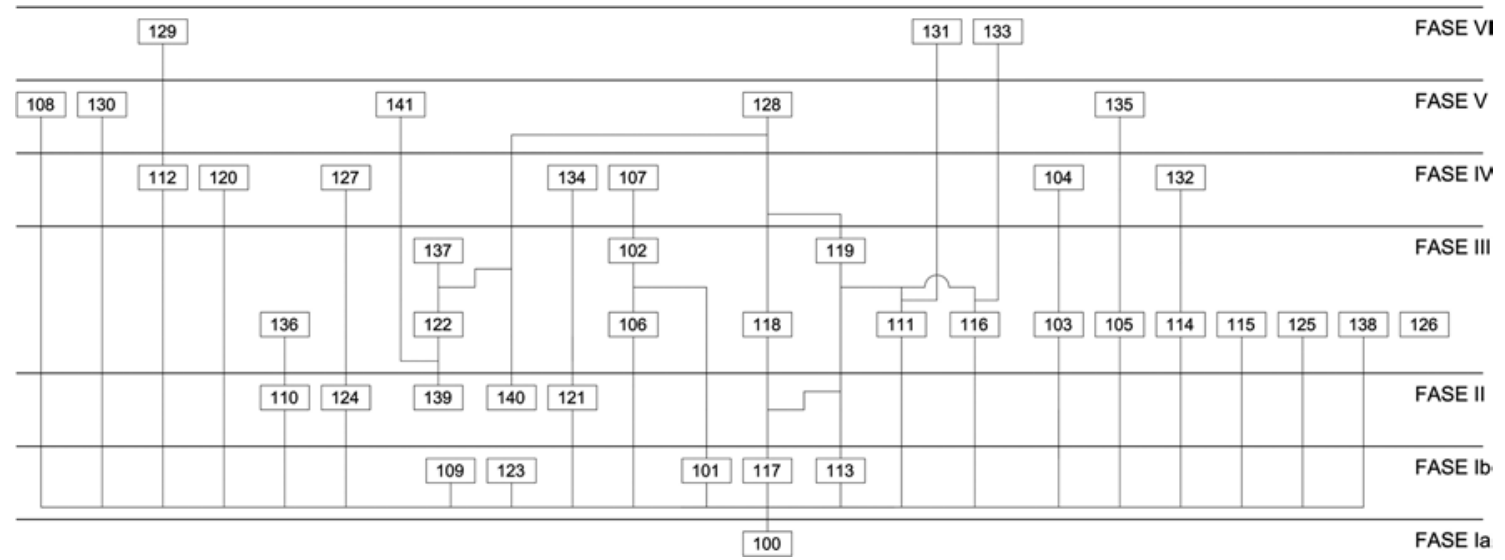

Diagrama estratigráfico

\begin{tabular}{|c|c|c|c|c|c|c|c|c|c|}
\hline Fase & A & Nombre A & UE & Nombre UE & Fig. & Ant. a A & Post. a A & Ant. a UE & Post. a UE \\
\hline \multirow[t]{9}{*}{$1 a$} & \multirow[t]{9}{*}{100} & \multirow[t]{9}{*}{$\begin{array}{l}\text { Iglesia } \\
\text { originaria }\end{array}$} & 1000 & Ábside este & 2320 & $\begin{array}{ll}101 & 102 \\
103 & 104 \\
106 & 107 \\
129 & \end{array}$ & & $\begin{array}{|ll|}1001 & 1002 \\
1003 & 1004 \\
1005 & 1007 \\
1008 & 1009 \\
1011 & \\
\end{array}$ & \\
\hline & & & 1013 & Habitación sur & 237 & $\begin{array}{ll}100 & 108 \\
109 & 119 \\
128 & 129\end{array}$ & & $\begin{array}{|ll|}1005 & 1014 \\
1016 & 1017 \\
1018 & 1019 \\
1021\end{array}$ & \\
\hline & & & 1018 & $\begin{array}{l}\text { Corte pieza ángulo occidental } \\
\text { muro sur habitación sur }\end{array}$ & 2 & 100 & & 1013 & \\
\hline & & & 1024 & Habitación norte & 3720 & $\begin{array}{ll}100 & 110 \\
112 & 119 \\
121 & 128 \\
129 & 130\end{array}$ & & $\begin{array}{|lll|}1005 & 1025 \\
1026 & 1027 \\
1028 & 1031 \\
1032 & 1033 \\
1042 & 1067 \\
1068 & & \\
\end{array}$ & \\
\hline & & & 1028 & Imposta habitación norte & 3720 & 111119 & 100 & 10291031 & 1024 \\
\hline & & & 1034 & Nave & $\begin{array}{l}237 \\
20\end{array}$ & $\begin{array}{ll}100 & 110 \\
115 & 117 \\
118 & 119 \\
124 & 125 \\
126 & 127 \\
128 & 133\end{array}$ & & $\begin{array}{|lll|}1035 & 1043 \\
1047 & 1048 \\
1049 & 1050 \\
1052 & 1056 \\
1058 & 1072 \\
1074 & 1075 \\
1076 & 1077 \\
1078 & 1079 \\
1080 & 1081 \\
1082 & 1083 \\
1084 & 1085 \\
\end{array}$ & \\
\hline & & & 1053 & Ábside oeste & 2720 & & $\begin{array}{ll}110 & 116 \\
117 & 119 \\
121 & 123 \\
129 & 133 \\
134 & \\
\end{array}$ & & $\begin{array}{lll}1052 & 1054 \\
1055 & 1060 \\
1062 & 1063 \\
1065 & 1066 \\
1071 & 1100 \\
\end{array}$ \\
\hline & & & 1074 & $\begin{array}{l}\text { Modillones originarios tramo } \\
\text { este nave }(5,7,26,27,29,36 \text {, } \\
37 \text { ) }\end{array}$ & 220 & 119 & & 1035 & \\
\hline & & & 1100 & $\begin{array}{l}\text { Umbral y celosía vano Ábside } \\
\text { oeste }\end{array}$ & 7 & 120 & 100 & 1064 & 1053 \\
\hline
\end{tabular}




\begin{tabular}{|c|c|c|c|c|c|c|c|c|c|}
\hline Fase & A & Nombre A & UE & Nombre UE & Fig. & Ant. a A & Post. a A & Ant. a UE & Post. a UE \\
\hline \multirow[t]{12}{*}{$1 b$} & \multirow[t]{2}{*}{101} & \multirow[t]{2}{*}{$\begin{array}{l}\text { Construcción } \\
\text { adosada } \\
\text { cabecera }\end{array}$} & 1001 & $\begin{array}{l}\text { Serie vertical de agujeros } \\
\text { ángulo norte fachada E } \\
\text { ábside }\end{array}$ & 3 & 102 & 100 & 1004 & 1000 \\
\hline & & & 1002 & $\begin{array}{l}\text { Serie vertical de agujeros } \\
\text { ángulo sur fachada E ábside }\end{array}$ & 3 & 102 & 100 & 1004 & 1000 \\
\hline & 109 & $\begin{array}{l}\text { Edificación } \\
\text { adosada } \\
\text { sobre habita- } \\
\text { ción sur } \\
\end{array}$ & 1019 & $\begin{array}{l}\text { Agujeros fachada sur habita- } \\
\text { ción sur }\end{array}$ & 2 & 129 & 100 & 1005 & 1013 \\
\hline & \multirow[t]{3}{*}{113} & \multirow{3}{*}{$\begin{array}{l}\text { Edificación } \\
\text { adosada } \\
\text { sobre facha- } \\
\text { da norte aula }\end{array}$} & 1036 & $\begin{array}{l}\text { Pareja de agujeros a ambos } \\
\text { lados arcos puerta norte }\end{array}$ & 20 & 119 & 100 & 1037 & 1034 \\
\hline & & & 1040 & $\begin{array}{l}\text { Agujero junto a contrafuerte } \\
\text { noroccidental aula }\end{array}$ & 20 & 129 & 100 & 1062 & 1034 \\
\hline & & & 1041 & $\begin{array}{l}\text { Línea agujeros bajo ventana } \\
\text { norte aula }\end{array}$ & 20 & 119 & 100 & 1035 & 1034 \\
\hline & \multirow[t]{5}{*}{117} & \multirow{5}{*}{$\begin{array}{l}\text { Pórtico ado- } \\
\text { sado fachada } \\
\text { sur aula }\end{array}$} & 1048 & $\begin{array}{l}\text { Línea de pizarras fachada } \\
\text { meridional aula }\end{array}$ & 2 & 119 & 100 & 1035 & 1034 \\
\hline & & & 1049 & $\begin{array}{l}\text { Gran roza en fachada meri- } \\
\text { dional aula }\end{array}$ & 2 & 119 & 100 & 1051 & 1034 \\
\hline & & & 1050 & $\begin{array}{l}\text { Línea superior agujeros en } \\
\text { fachada meridional aula }\end{array}$ & 2 & 119 & 100 & 1051 & 1034 \\
\hline & & & 1056 & $\begin{array}{l}\text { Cortes en tímpano arco des- } \\
\text { carga fachada sur aula }\end{array}$ & 2 & 118 & 100 & 1057 & 1034 \\
\hline & & & 1060 & $\begin{array}{l}\text { Agujero parte media muro } \\
\text { sur Ábside oeste }\end{array}$ & 2 & & 100 & & 1053 \\
\hline & 123 & $\begin{array}{l}\text { Línea aguje- } \\
\text { ros fachada } \\
\text { norte Ábside } \\
\text { oeste } \\
\end{array}$ & 1071 & $\begin{array}{l}\text { Línea agujeros fachada norte } \\
\text { Ábside oeste }\end{array}$ & 20 & & 100 & & 1053 \\
\hline \multirow[t]{12}{*}{2} & \multirow[t]{4}{*}{110} & \multirow[t]{4}{*}{ Inscripciones } & 1020 & $\begin{array}{l}\text { Inscripción junto a ventana } \\
\text { habitación sur }\end{array}$ & 2 & & 100 & & 1013 \\
\hline & & & 1033 & $\begin{array}{l}\text { Inscripción muro oeste habi- } \\
\text { tación norte }\end{array}$ & 7 & & 100 & & 1024 \\
\hline & & & 1063 & $\begin{array}{l}\text { Inscripción parte baja muro } \\
\text { oeste Ábside oeste }\end{array}$ & 7 & & 100 & & 1053 \\
\hline & & & 1085 & $\begin{array}{l}\text { Inscripción en jamba oriental } \\
\text { puesta norte aula }\end{array}$ & 20 & 136 & 100 & 1089 & 1034 \\
\hline & \multirow[t]{2}{*}{121} & \multirow[t]{2}{*}{$\begin{array}{l}\text { Cerca cemen- } \\
\text { terial }\end{array}$} & 1066 & $\begin{array}{l}\text { Muro norte-sur ángulo } \\
\text { noroccidental Ábside oeste }\end{array}$ & 720 & 134 & 100 & 1065 & 1053 \\
\hline & & & 1067 & $\begin{array}{l}\text { Muro este-oeste ángulo } \\
\text { noroccidental habitación } \\
\text { norte }\end{array}$ & 1720 & & 100 & & 1024 \\
\hline & \multirow[t]{6}{*}{124} & \multirow{6}{*}{$\begin{array}{l}\text { Recolocación } \\
\text { modillones } \\
\text { originarios } \\
\text { tramo este } \\
\text { aula }\end{array}$} & 1073 & $\begin{array}{l}\text { Modillones recolocados cara } \\
\text { norte y sur transepto este } \\
\text { nave }(3,4,8,9,10,11,2542 \\
43 \text { y } 44)\end{array}$ & & 119 & & 1035 & \\
\hline & & & 1076 & $\begin{array}{l}\text { Modillones sobre cajeado } \\
\text { cara este tramo este nave } \\
(14 \text { y } 25)\end{array}$ & 3 & 119 & 100 & 1035 & 1034 \\
\hline & & & 1078 & $\begin{array}{l}\text { Modillones sin labrar cara } \\
\text { este tramo este nave (17 y } \\
18)\end{array}$ & 3 & 119 & & 1035 & \\
\hline & & & 1079 & $\begin{array}{l}\text { Modillones sin labrar cara } \\
\text { este tramo este nave (19 y } \\
\text { 22) }\end{array}$ & 3 & 119 & 100 & 1035 & 1034 \\
\hline & & & 1083 & $\begin{array}{l}\text { Modillones calzados cara } \\
\text { oeste tramo este nave (38 } \\
\text { y } 39 \text { ) }\end{array}$ & 7 & 119 & & 1035 & \\
\hline & & & 1084 & $\begin{array}{l}\text { Modillones planos cara oeste } \\
\text { tramo este nave ( } 40 \text { y } 41)\end{array}$ & 7 & 119 & & 1035 & \\
\hline
\end{tabular}




\begin{tabular}{|c|c|c|c|c|c|c|c|c|c|}
\hline \multirow[t]{5}{*}{ (2) } & \multirow[t]{4}{*}{139} & \multirow{4}{*}{$\begin{array}{l}\text { Edificación a } \\
\text { oeste de igle- } \\
\text { sia originaria }\end{array}$} & 1093 & $\begin{array}{l}\text { Muro este-oeste al sur } \\
\text { espadaña }\end{array}$ & 1 & 128141 & & 10971099 & \\
\hline & & & 1094 & $\begin{array}{l}\text { Muro norte-sur al sur espa- } \\
\text { daña }\end{array}$ & 1 & 122 & & 1069 & \\
\hline & & & 1095 & $\begin{array}{l}\text { Muro norte-sur al norte } \\
\text { espadaña }\end{array}$ & 1 & 122 & & 1069 & \\
\hline & & & 1096 & $\begin{array}{l}\text { Muro este-oeste al norte } \\
\text { espadaña }\end{array}$ & 1 & 128141 & & 10981099 & \\
\hline & 140 & $\begin{array}{l}\text { Edificación a } \\
\text { sur de iglesia } \\
\text { originaria }\end{array}$ & 1092 & $\begin{array}{l}\text { Muro este-oeste al sur iglesia } \\
\text { con pintura }\end{array}$ & 1 & 128 & & 10681097 & \\
\hline \multirow[t]{26}{*}{3} & 102 & $\begin{array}{l}\text { Nuevo enfos- } \\
\text { cado general }\end{array}$ & 1004 & $\begin{array}{l}\text { Enfoscado cuerpo superior } \\
\text { ábside }\end{array}$ & 2320 & $\begin{array}{|ll|}103 & 107 \\
129 & \\
\end{array}$ & $\begin{array}{|ll|}100 & 101 \\
106 & \\
\end{array}$ & $\begin{array}{l}10051009 \\
1011\end{array}$ & $\begin{array}{l}10001001 \\
10021003 \\
\end{array}$ \\
\hline & \multirow[t]{3}{*}{103} & \multirow{3}{*}{$\begin{array}{l}\text { Apertura } \\
\text { vano lateral } \\
\text { ábside }\end{array}$} & 1007 & $\begin{array}{l}\text { Vano en muro norte ábside } \\
\text { central }\end{array}$ & 20 & 104 & 100 & 1008 & 1000 \\
\hline & & & 1009 & $\begin{array}{l}\text { Corte ángulo noroeste muro } \\
\text { norte ábside }\end{array}$ & 20 & 103 & 100 & 1010 & 1000 \\
\hline & & & 1010 & $\begin{array}{l}\text { Muro superior con imposta y } \\
\text { alero muro norte ábside }\end{array}$ & 20 & 102 & 103 & 1004 & 1009 \\
\hline & 105 & $\begin{array}{l}\text { Cierre ven- } \\
\text { tana ábside } \\
\text { central }\end{array}$ & 1006 & $\begin{array}{l}\text { Serie vertical de agujeros en } \\
\text { jamba sur ventana ábside } \\
\text { central }\end{array}$ & 3 & 129 & 100 & 1062 & 1000 \\
\hline & 106 & $\begin{array}{l}\text { Reparación } \\
\text { cornisa } \\
\text { ábside }\end{array}$ & 1003 & Cornisa ábside & 2320 & 102 & 100 & 1004 & 1000 \\
\hline & 111 & $\begin{array}{l}\text { Alero habita- } \\
\text { ción norte }\end{array}$ & 1029 & $\begin{array}{l}\text { Modillones y alero habita- } \\
\text { ción norte }\end{array}$ & 2320 & 119131 & 100 & 10301031 & 1024 \\
\hline & \multirow[t]{2}{*}{114} & \multirow{2}{*}{$\begin{array}{l}\text { Reconstruc- } \\
\text { ción alero } \\
\text { tramo oeste } \\
\text { aula } \\
\end{array}$} & 1044 & $\begin{array}{l}\text { Imposta y alero con modillo- } \\
\text { nes muro norte aula }\end{array}$ & 20 & & 100 & & 1034 \\
\hline & & & 1046 & $\begin{array}{l}\text { Imposta y alero con modillo- } \\
\text { nes muro sur aula }\end{array}$ & 27 & & 100 & & 1034 \\
\hline & 115 & Reja & 1047 & $\begin{array}{l}\text { Agujeros en jambas ventana } \\
\text { sur aula }\end{array}$ & 2 & 133 & 100 & 1052 & 1034 \\
\hline & 116 & $\begin{array}{l}\text { Cuerpo supe- } \\
\text { rior Ábside } \\
\text { oeste }\end{array}$ & 1054 & $\begin{array}{l}\text { Cuerpo superior Ábside } \\
\text { oeste }\end{array}$ & 2720 & 119 & 100 & 1055 & 10341053 \\
\hline & \multirow[t]{3}{*}{118} & \multirow{3}{*}{$\begin{array}{l}\text { Reforma pór- } \\
\text { tico adosado } \\
\text { fachada sur } \\
\text { aula }\end{array}$} & 1057 & Relleno UE1056 & 2 & 119 & 117 & 1059 & 1056 \\
\hline & & & 1058 & $\begin{array}{l}\text { Línea inferior agujeros facha- } \\
\text { da sur aula }\end{array}$ & 2 & 119 & 100 & 1059 & 1034 \\
\hline & & & 1061 & Relleno UE1060 & & & 117 & & 1060 \\
\hline & \multirow[t]{7}{*}{119} & \multirow{7}{*}{$\begin{array}{l}\text { Cargas de } \\
\text { mortero } \\
\text { pizarroso } \\
\text { generalizado }\end{array}$} & 1017 & $\begin{array}{l}\text { Enfoscado superior habita- } \\
\text { ción sur }\end{array}$ & 237 & 128 & 100 & 1022 & $\begin{array}{l}10131015 \\
1016 \\
\end{array}$ \\
\hline & & & 1021 & $\begin{array}{l}\text { Parte intermedia contrafuer- } \\
\text { te occidental habitación sur }\end{array}$ & 27 & 128 & 100 & 1022 & 1013 \\
\hline & & & 1031 & $\begin{array}{l}\text { Enfoscado parte superior } \\
\text { habitación norte }\end{array}$ & 3720 & 129 & 100111 & 1005 & $\begin{array}{l}10241028 \\
1029 \\
\end{array}$ \\
\hline & & & 1035 & Enfoscado pizarroso aula & 220 & 114132 & $\begin{array}{ll}100 & 113 \\
119 & \end{array}$ & 10381039 & $\begin{array}{l}10341037 \\
10411053 \\
1055\end{array}$ \\
\hline & & & 1037 & $\begin{array}{l}\text { Relleno pareja agujeros } \\
\text { UE1036 }\end{array}$ & 20 & 119 & 113 & 1035 & 1036 \\
\hline & & & 1051 & Relleno UE1049 y 1050 & 2 & & 100117 & & $\begin{array}{l}10341049 \\
1050 \\
\end{array}$ \\
\hline & & & 1055 & $\begin{array}{l}\text { Reforma enfoscado pizarroso } \\
\text { parte media muro sur Ábside } \\
\text { oeste }\end{array}$ & 2 & & 100116 & & 10341054 \\
\hline & 122 & Espadaña & 1069 & Espadaña & & 128137 & 139 & 10701090 & 10941095 \\
\hline & \multirow[t]{3}{*}{125} & \multirow{3}{*}{$\begin{array}{l}\text { Renovación } \\
\text { modillones } \\
\text { central y } \\
\text { ángulos en } \\
\text { fachada sur } \\
\text { y este tramo } \\
\text { este aula }\end{array}$} & 1072 & $\begin{array}{l}\text { Modillones de la esquina } \\
\text { suroeste tramo este nave ( } 1 \text {, } \\
2 \text { y } 6)\end{array}$ & 27 & 119 & 100 & 1035 & 1034 \\
\hline & & & 1075 & $\begin{array}{l}\text { Modillones esquina sureste } \\
\text { tramo este nave }\end{array}$ & 23 & 119 & 100 & 1035 & 1034 \\
\hline & & & 1077 & $\begin{array}{l}\text { Modillón nacelado cara este } \\
\text { tramo este nave (16) }\end{array}$ & 3 & 119 & & 1035 & \\
\hline & 126 & $\begin{array}{l}\text { Renovación } \\
\text { modillón cen- } \\
\text { tral fachada } \\
\text { norte tramo } \\
\text { este aula }\end{array}$ & 1081 & $\begin{array}{l}\text { Modillones con inscripción } \\
\text { cara norte tramo este nave } \\
\text { (28) }\end{array}$ & 20 & & & & \\
\hline
\end{tabular}




\begin{tabular}{|c|c|c|c|c|c|c|c|c|c|}
\hline \multirow[t]{3}{*}{ (3) } & 136 & $\begin{array}{l}\text { Cegado puer- } \\
\text { ta norte }\end{array}$ & 1089 & Cegado puerta norte & 20 & & 100110 & & 10341085 \\
\hline & 137 & $\begin{array}{l}\text { Cargas de } \\
\text { mortero } \\
\text { pizarroso en } \\
\text { espadaña } \\
\end{array}$ & 1090 & $\begin{array}{l}\text { Enfoscado pizarroso en } \\
\text { espadaña }\end{array}$ & & & 122 & & 1069 \\
\hline & 138 & $\begin{array}{l}\text { Coro o púl- } \\
\text { pito }\end{array}$ & 1038 & $\begin{array}{l}\text { Corte a occidente de la puer- } \\
\text { ta norte aula }\end{array}$ & 20 & 132 & 100 & 1039 & 1034 \\
\hline \multirow[t]{9}{*}{4} & 104 & $\begin{array}{l}\text { Cierre vano } \\
\text { lateral ábside }\end{array}$ & 1008 & $\begin{array}{l}\text { Relleno vano en muro norte } \\
\text { ábside central }\end{array}$ & 20 & & 103 & & 10071010 \\
\hline & \multirow[t]{2}{*}{107} & \multirow[t]{2}{*}{$\begin{array}{l}\text { Reparación } \\
\text { alero ábside }\end{array}$} & 1011 & $\begin{array}{l}\text { Corte ángulo sureste muro } \\
\text { sur ábside }\end{array}$ & 2 & 107 & 100102 & 1012 & 10001004 \\
\hline & & & 1012 & $\begin{array}{l}\text { Muro ángulo sureste con } \\
\text { cornisa y modillón muro sur } \\
\text { ábside }\end{array}$ & 2 & & 107 & & 1011 \\
\hline & 112 & $\begin{array}{l}\text { Deformación } \\
\text { o elementos } \\
\text { adosados }\end{array}$ & 1032 & $\begin{array}{l}\text { Corte y deformación muro } \\
\text { norte habitación norte }\end{array}$ & 20 & 129 & 100 & 1005 & 1013 \\
\hline & 120 & $\begin{array}{l}\text { Rotura celo- } \\
\text { sía ventana }\end{array}$ & 1064 & $\begin{array}{l}\text { Rotura celosía ventana occi- } \\
\text { dental ábside oeste }\end{array}$ & 7 & 133 & 100 & 1052 & 1100 \\
\hline & \multirow[t]{2}{*}{127} & \multirow{2}{*}{$\begin{array}{l}\text { Renovación } \\
\text { modillones } \\
\text { ángulos e } \\
\text { inmediatos } \\
\text { fachada } \\
\text { norte tramo } \\
\text { este aula }\end{array}$} & 1080 & $\begin{array}{l}\text { Modillones esquina noreste } \\
\text { tramo este nave (23 y } 24)\end{array}$ & 3 & 128 & 124 & 1091 & 10731079 \\
\hline & & & 1082 & $\begin{array}{l}\text { Modillones occidentales cara } \\
\text { norte tramo este nave ( } 30 \\
\text { y } 35)\end{array}$ & 720 & & 100 & & 1034 \\
\hline & 132 & $\begin{array}{l}\text { Cierre puerta } \\
\text { acceso coro } \\
\text { o púlpito }\end{array}$ & 1039 & Relleno UE1038 & 20 & & 114 & & 1038 \\
\hline & 134 & Cenotafio & 1065 & Cenotafio & 720 & 129 & 100121 & 1062 & $\begin{array}{l}10341053 \\
1066\end{array}$ \\
\hline \multirow[t]{19}{*}{5} & \multirow[t]{2}{*}{108} & \multirow{2}{*}{$\begin{array}{l}\text { Alero de } \\
\text { madera de } \\
\text { habitación } \\
\text { sur }\end{array}$} & 1015 & Imposta habitación sur & 237 & 108 & 100 & 10161017 & 1013 \\
\hline & & & 1016 & $\begin{array}{l}\text { Cubierta de madera habita- } \\
\text { ción sur }\end{array}$ & 237 & & 108 & & 1015 \\
\hline & \multirow[t]{13}{*}{128} & \multirow{13}{*}{$\begin{array}{l}\text { Restauración } \\
\text { Menéndez } \\
\text { Pidal }\end{array}$} & 1014 & $\begin{array}{l}\text { Parte superior contrafuerte } \\
\text { oriental habitación sur }\end{array}$ & 23 & & 100 & & 1013 \\
\hline & & & 1022 & $\begin{array}{l}\text { Parche superior contrafuerte } \\
\text { occidental habitación sur }\end{array}$ & 27 & & 100119 & & 10131021 \\
\hline & & & 1023 & $\begin{array}{l}\text { Agujeros junto cara sur con- } \\
\text { trafuerte occidental habita- } \\
\text { ción sur }\end{array}$ & 7 & & 100 & & 1013 \\
\hline & & & 1025 & $\begin{array}{l}\text { Contrafuerte oriental habita- } \\
\text { ción norte }\end{array}$ & 3 & & 100 & & 1024 \\
\hline & & & 1042 & $\begin{array}{l}\text { Parte alta contrafuerte occi- } \\
\text { dental habitación norte }\end{array}$ & 720 & & 100 & & 1024 \\
\hline & & & 1043 & $\begin{array}{l}\text { Parte alta contrafuertes aula } \\
\text { norte }\end{array}$ & 720 & 131 & 100 & 1030 & 1034 \\
\hline & & & 1045 & $\begin{array}{l}\text { Parte alta contrafuertes aula } \\
\text { sur }\end{array}$ & 2 & & 100 & & 1034 \\
\hline & & & 1059 & Relleno UE1058 & 2 & & 118 & & 1058 \\
\hline & & & 1068 & $\begin{array}{l}\text { Muro pantalla a este de iglesia } \\
\text { originaria }\end{array}$ & 1320 & 140 & 100128 & 1092 & 10241025 \\
\hline & & & 1070 & Escaleras en espadaña & & & 122 & & 1069 \\
\hline & & & 1091 & Cubierta hierro contrafuerte & 237 & 127 & & 1080 & \\
\hline & & & 1097 & Puerta sur recinto perimetral & 1 & & 139140 & & 10921093 \\
\hline & & & 1098 & $\begin{array}{l}\text { Cierre puerta al norte recinto } \\
\text { perimetral }\end{array}$ & 1 & & 121139 & & 10671096 \\
\hline & \multirow[t]{4}{*}{130} & \multirow{4}{*}{$\begin{array}{l}\text { Restauración } \\
\text { muro oriental } \\
\text { habitación } \\
\text { norte }\end{array}$} & 1026 & $\begin{array}{l}\text { Gran corte muro oriental habi- } \\
\text { tación norte }\end{array}$ & 3 & 130 & 100 & 1087 & 1024 \\
\hline & & & 1027 & $\begin{array}{l}\text { Inscripción junto a ventana } \\
\text { oriental habitación norte }\end{array}$ & 3 & & 100 & & 1024 \\
\hline & & & 1087 & $\begin{array}{l}\text { Relleno de gran corte muro } \\
\text { este habitación norte }\end{array}$ & 3 & & 130 & & 1026 \\
\hline & & & 1088 & $\begin{array}{l}\text { Relleno inferior aspillera muro } \\
\text { este habitación norte }\end{array}$ & 3 & & 100 & & 1024 \\
\hline
\end{tabular}




\begin{tabular}{|c|c|c|c|c|c|c|c|}
\hline \multirow[t]{2}{*}{ (5) } & 135 & $\begin{array}{l}\text { Reja en ven- } \\
\text { tana ábside }\end{array}$ & 1086 & $\begin{array}{l}\text { Corte para reja en ventana } \\
\text { ábside }\end{array}$ & 3 & 100105 & $\begin{array}{l}10001005 \\
1006\end{array}$ \\
\hline & 141 & $\begin{array}{l}\text { Edificacio- } \\
\text { nes al oeste } \\
\text { del recinto } \\
\text { perimetral } \\
\end{array}$ & 1099 & $\begin{array}{l}\text { Muros este-oeste a sury norte } \\
\text { del extremo occidental de } \\
\text { iglesia }\end{array}$ & 1 & 139 & 10931096 \\
\hline \multirow[t]{4}{*}{6} & \multirow[t]{2}{*}{129} & \multirow{2}{*}{$\begin{array}{l}\text { Restauracio- } \\
\text { nes contem- } \\
\text { poráneas con } \\
\text { cemento }\end{array}$} & 1005 & $\begin{array}{l}\text { Rejuntado cementoso cuerpo } \\
\text { inferior ábside }\end{array}$ & 2320 & 100112 & $\begin{array}{l}10001013 \\
10241032\end{array}$ \\
\hline & & & 1062 & $\begin{array}{l}\text { Parches de cemento en aula } \\
\text { y cenotafio }\end{array}$ & $\begin{array}{l}237 \\
20\end{array}$ & 100113 & $\begin{array}{l}10131024 \\
10341040 \\
1053\end{array}$ \\
\hline & 131 & $\begin{array}{l}\text { Cubierta } \\
\text { habitación } \\
\text { norte y } \\
\text { tejadillo } \\
\text { contrafuerte } \\
\text { noroeste } \\
\text { aula } \\
\end{array}$ & 1030 & $\begin{array}{l}\text { Cubierta habitación norte y } \\
\text { tejadillo contrafuerte noroeste } \\
\text { aula }\end{array}$ & 3720 & 111 & 1029 \\
\hline & 133 & $\begin{array}{l}\text { Piezas de } \\
\text { alabastro en } \\
\text { ventanas }\end{array}$ & 1052 & $\begin{array}{l}\text { Piezas de alabastro en ven- } \\
\text { tanas }\end{array}$ & $\begin{array}{lll}2 & 3 & 7 \\
20 & \end{array}$ & 100116 & 10341054 \\
\hline
\end{tabular}

